\title{
WestVirginiaUniversity
}

THE RESEARCH REPOSITORY @ WVU

West Virginia Agricultural and Forestry Experiment

Davis College of Agriculture, Natural Resources

Station Bulletins

And Design

$1-1-1975$

\section{Factors affecting rural land values along Corridor E in West Virginia}

Andrew N. Dufresne

Dale Colyer

Follow this and additional works at: https://researchrepository.wvu.edu/

wv_agricultural_and_forestry_experiment_station_bulletins

\section{Digital Commons Citation}

Dufresne, Andrew N. and Colyer, Dale, "Factors affecting rural land values along Corridor E in West Virginia" (1975). West Virginia Agricultural and Forestry Experiment Station Bulletins. 639.

https://researchrepository.wvu.edu/wv_agricultural_and_forestry_experiment_station_bulletins/546

This Bulletin is brought to you for free and open access by the Davis College of Agriculture, Natural Resources And Design at The Research Repository @ WVU. It has been accepted for inclusion in West Virginia Agricultural and Forestry Experiment Station Bulletins by an authorized administrator of

The Research Repository@WVU. For more information, please contact ian.harmon@mail.wvu.edu. 


\section{Factors Affecting Rural}

Land Values Along Corridor E

In West Virginia

Bulletin 639

August 1975

West Virginia University Agricultural Experiment Station

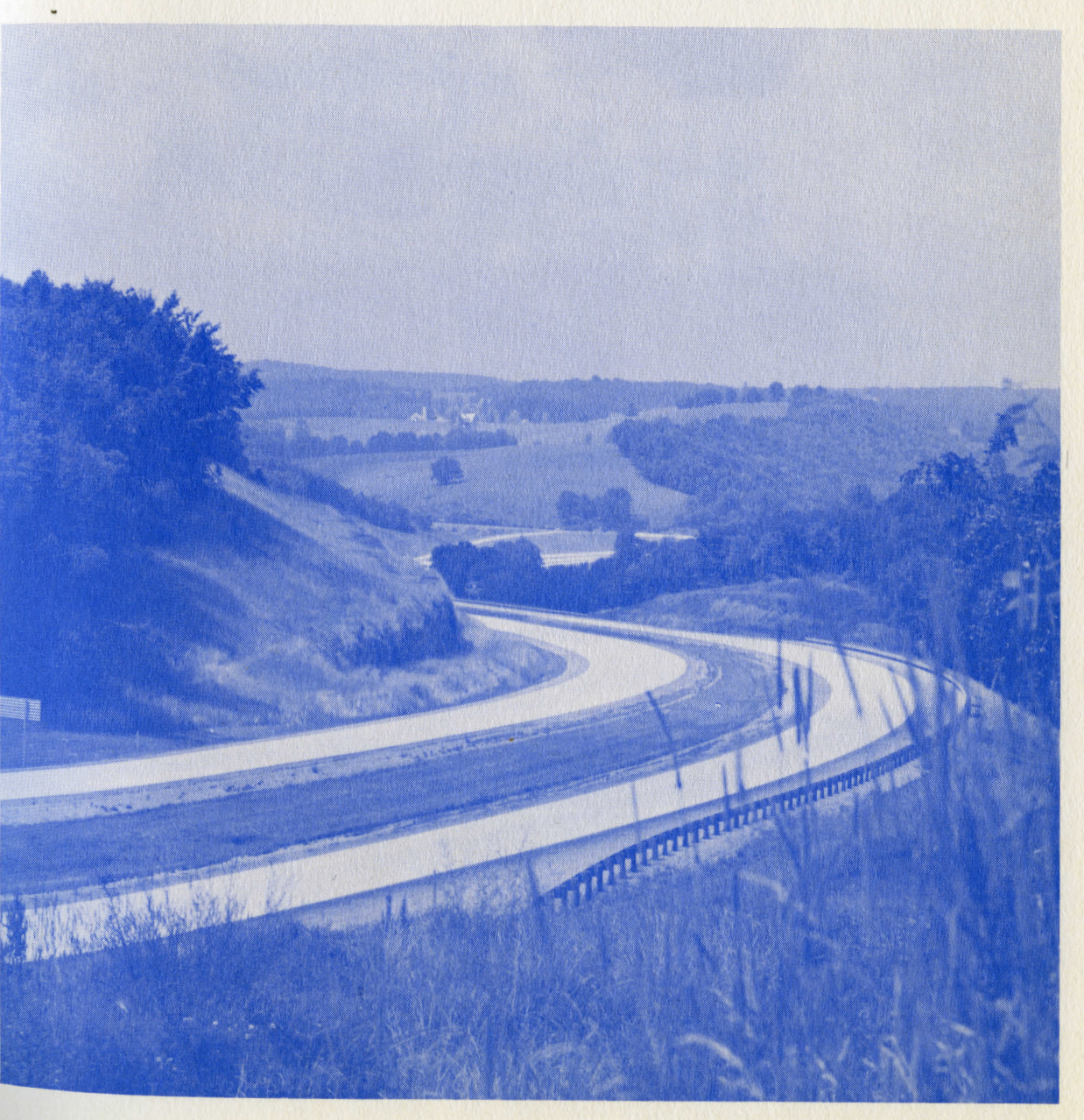




\section{The Authors}

At the time of this study, Andrew N. Dufresne was Graduate Research Assistant in Agricultural Economics; Dale Colyer is Agricultural Scientist in Agricultural Economics, Division of Resource Management, Agricultural Experiment Station, West Virginia University.

\section{ABSTRACT}

Land records of Preston and Monongalia counties in West Virginia for the 1966-1971 period were used to obtain information on 1,093 parcels of rural land transferred near the right-of-way of the Corridor E Appalachian Development Highway. Over half of the sales were for parcels of one acre or less, with a substantial share of these located in rural subdivisions, i.e., formally platted subdivisions not located within an incorporated area. Prices varied with location, size, and other factors and increased through time. Regressica models using physical, locational, and transfer characteristics were employed to explain per acre land prices. Locational factors were the more important explanatory variables. No detectable effect on private transfers was found for the highway being built through the area.

WEST VIRGINIA UNIVERSITY AGRICULTURAL EXPERIMENT STATION COLLEGE OF AGRICULTURE AND FORESTRY DALE W. ZINN, DIRECTOR MORGANTOWN

\section{Contents}

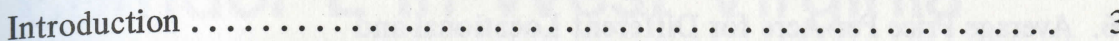

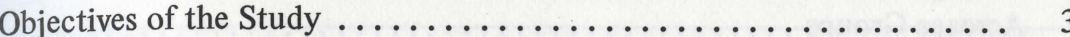

Methodology............................... 4

Description of the Study Area ................... 4

Analysis of Land Transactions $\ldots \ldots \ldots \ldots \ldots \ldots \ldots \ldots \ldots \ldots$

Limitation of Acreage and Consideration Data............... 8

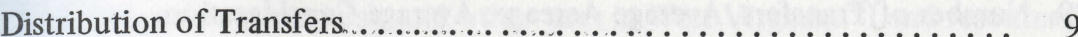

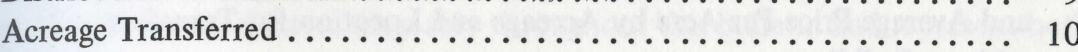

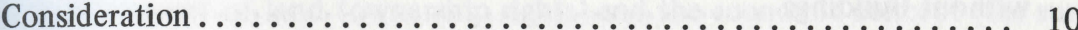

Price Per Acre ........................... 10

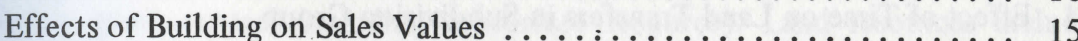

Influence of Time............................ 16

Regression Analysis................................ 23

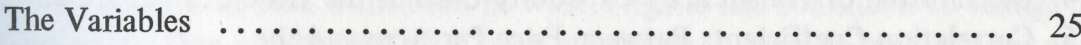

Correlations ............................... 28

The Multiple Regression Models .......................... 29

Relative Importance of Different Groups of Variables ........... 35

Summary and Conclusions ...................... 37

Bibliography ............................ 43

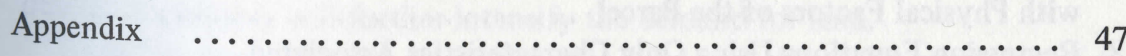


1. Population Data .................. 7

2. Distribution of Number of Transfers by Year and Location ....... 9

3. Acreage Transferred by Size of Parcel and Location ............. 11

4. Average and Total Consideration by Size of Parcel and Location...... 12

5. Number of Transfers and Average Consideration by Value Class and Location ....

6. Average Price Per Acre for Different Locational and Acreage Groups ................................ 15

7. Effects of Buildings on Transfers ..................... 16

8. Number of Transfers, Average Acreage, Average Consideration, and Average Price Per Acre by Acreage and Location for Transfers

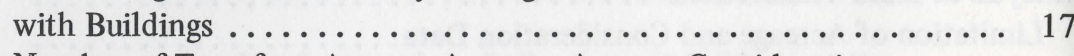

9. Number of Transfers, Average Acreage, Average Consideration, and Average Price Per Acre by Acreage and Location for Transfers without Buildings

10. Effect of Time on Land Transfers in the Study Area .....................

11. Effect of Time on Land Transfers in Subdivision Group .......... 22

12. Effect of Time on Land Transfers in Monongalia Group .......... 24

13. Effect of Time on Land Transfers in Preston Group ............ 24

14. Distribution of Transfers by Capability Class of the Land ......... 27

15. Correlation Coefficients Between Price Per Acre and the Independent Variables Used in Land Market Models ........... 29

16. Regression Coefficients, T-Values, and Standard B Values for the Independent Variables used to Explain Variations in the Price Per Acre of Rural Properties ............................... with Physical Factors of the Parcel ...................

18. Regression Equations Using Only Characteristics Associated with the Location of the Parcel ..................... 38

19. Regression Equations Using Only Characteristics Associated with the Transfer of the Parcel

\section{FIGURES}

1. The study area, Appalachian Development Highway "Corridor E" in Monongalia and Preston counties, West Virginia............

2. Average Price Per Acre by Acreage and Location for Transfers without Buildings

\section{Factors Affecting Rural Land Values Along Corridor E in West Virginia}

ANDREW N. DUFRESNE AND DALE COLYER

\section{Introduction}

D URAL LAND resources are important for agriculture, forestry, residential, 2 recreational, commercial, and other uses in West Virginia. "Land resources" and "land" are used interchangeably throughout this bulletin and represent both the legal concept of land (ownership rights) and the economic concept (the sum total of the natural and man-made resources over which possession of the earth's surface gives control including subsurface resource). Land resources include buildings and other capital improvements attached to the land. The term "rural" as used here and throughout includes all land not in a city or incorporated area.

The pattern of land utilization in West Virginia has continued to change in recent years. One notable shift has been a decrease in acres of land in farms and an increase in forest and other uses. A substantial turnover also has been occurring in land ownership in many parts of the state. Land values have been under increasing upward pressures as incomes and population have risen, tending to increase the demand for land. Completion of the limited access highway system will improve the accessibility to and from much of the interior of the state and probably will further intensify the demand for land.

Despite these changes relatively little is known about the operation of the land market or the factors influencing the price paid for land in rural market transactions in West Virginia. This study is a cross-sectional and time series investigation of land transactions in a defined area of Monongalia and Preston counties.

\section{OBJECTIVES OF THE STUDY}

A study of the land market at the West Virginia University Agricultural Experiment Station has the general objective of developing information and knowledge about the organization, structure and performance of the rural land market. The specific objectives for this part of that study are:

(1) To determine the nature of the organizational and operational characteristics of the rural land market in a specified area. 
(2) To identify and rank in significance the factors that affect the price of rural real estate in the selected area.

(3) To establish benchmark data useful in determining and evaluating the impact of Appalachian Corridor E Highway construction on adjacent land values and land use.

\section{METHODOLOGY}

Primary data on real estate transfers located within approximately two miles of Corridor E, exclusive of those within municipal limits, for the years 1966 through 1971 were obtained from transfer certificates, deed books and public land books. Name of the grantor and the grantee, the date of the transfer, acreage, consideration, building and land assessments (before and after the sale), tax class and location for 1,093 land transfers were recorded. Soil maps and aerial photographs were made available by the Soil Conservation Service and, in combination with tax maps acquired from the Office of the State Tax Commissioner, provided information on the soil, physical and land use characteristics of each land parcel transferred. Information on the location of public water systems and dates of installation were obtained from the Monongalia County Planning Commission and the comprehensive development plans of Monongalia and Preston counties. County highway maps furnished additional information on the locational characteristics of each land parcel.

Time series and cross-sectional analyses were performed on the data pertaining to acreage, consideration and price per acre. Tests of independence between these ratios and several factors were made. Multiple regression analysis was used to determine the relationship between the price per acre paid for a parcel of land and a set of hypothesized explanatory variables. Regression models were derived for different classes of properties and to show the relative importance of physical, locational, and transfer characteristics in explaining the variations in price per acre of rural properties.

\section{DESCRIPTION OF THE STUDY AREA}

The study area lies in Monongalia and Preston counties and includes land adjacent to the 32.5 miles of West Virginia Appalachian Corridor E highway.

The unit for selection into the study was the county tax map. Each tax map contains 2,507 acres, approximately 3.9 square miles, and shows the location, acreage, and boundaries for each parcel of land. A tax map was included in the study if a portion of it was within two miles of the route of Corridor E. Transfers located within a municipality were not included. The area thus selected included approximately 92,755 acres or 145 square miles (Figure 1). Of this area, 40,110 acres were in Monongalia County and 52,645 acres were in Preston County.

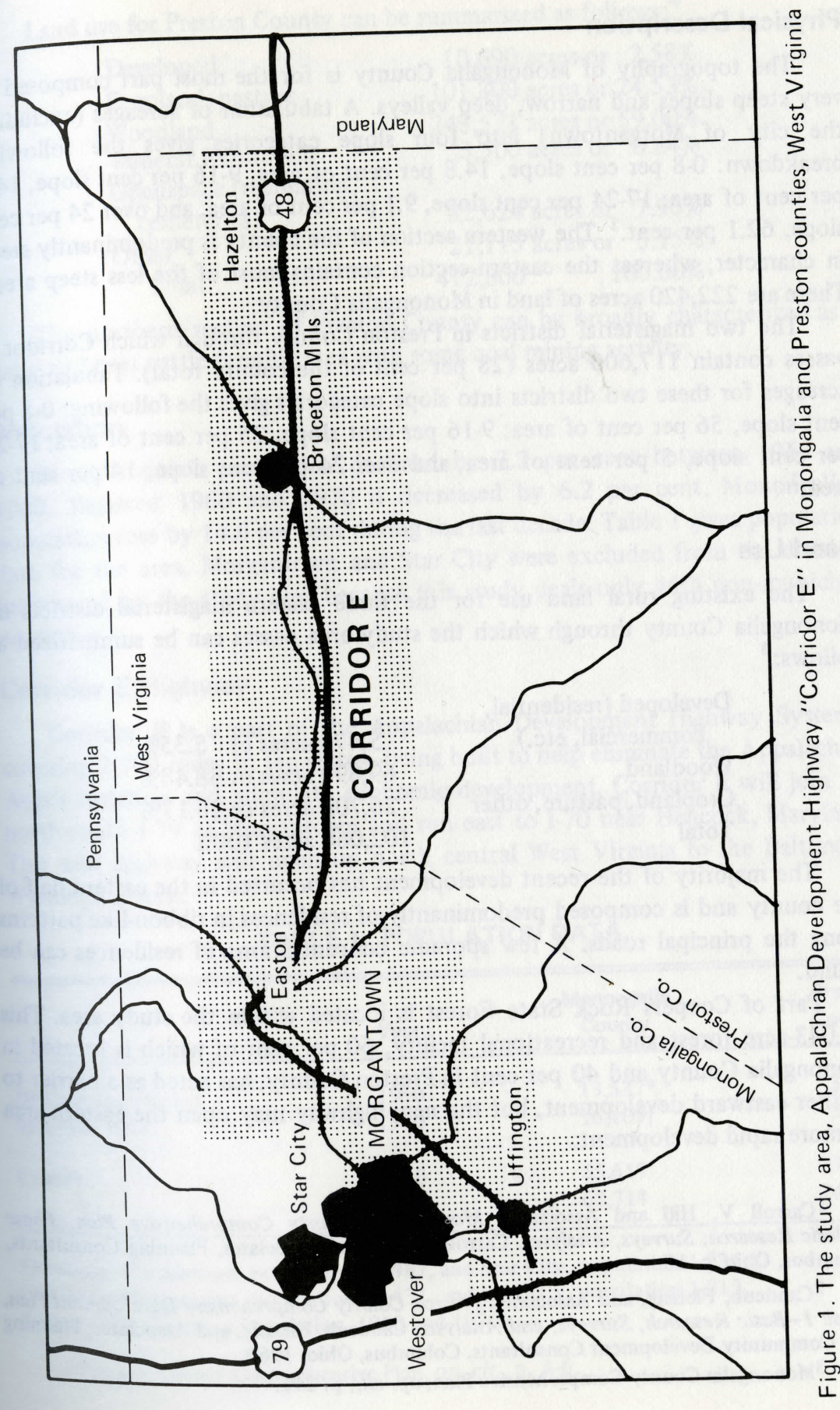




\section{Physical Description}

The topography of Monongalia County is for the most part composed of very steep slopes and narrow, deep valleys. A tabulation of acreages (excluding the city of Morgantown) into four slope categories gives the following breakdown: 0-8 per cent slope, 14.8 per cent of area; 9-16 per cent slope, 14.0 per cent of area; $17-24$ per cent slope, 9.1 per cent of area; and over 24 per cent slope, 62.1 per cent. ${ }^{1}$ The western section of the county is predominantly steep in character, whereas the eastern section contains most of the less steep areas. There are 222,420 acres of land in Monongalia County.

The two magisterial districts in Preston County through which Corridor E passes contain 117,600 acres. ( 28 per cent of the county total). Tabulation of acreages for these two districts into slope categories gives the following: 0-8 per cent slope, 56 per cent of area; 9-16 per cent slope, 25 per cent of area; 17-24 per cent slope, 5 per cent of area; and over 24 per cent slope, 14 per cent of area. $^{2}$

\section{Land Use}

The existing rural land use for the three eastern magisterial districts of Monongalia County through which the study area passes can be summarized as follows: ${ }^{3}$

$\begin{array}{lr}\text { Developed (residential, } & \\ \quad \text { commercial, etc.) } & 5,470 \text { acres or } 5.35 \% \\ \text { Woodland } & 69,890 \text { acres or } 68.48 \% \\ \text { Cropland, pasture, other } & 26,706 \text { acres or } 26.17 \% \\ \text { Total } & 102,066 \text { acres } 100 \%\end{array}$

The majority of the recent development has occurred in the eastern half of the county and is composed predominantly of residences in ribbon-like patterns along the principal roads. A few sporadic concentrations of residences can be found.

Part of Coopers Rock State Forest is located within the study area. This 13,043 -acre forest and recreational facility, 60 per cent of which is located in Monongalia County and 40 per cent in Preston County, has acted as a barrier to further eastward development, but the new highway may open the eastern area to more rapid development.

${ }^{1}$ Carroll V. Hill and Associates, Monongalia County Comprehensive Plan, Phase 1-Basic Research, Surveys, Analyses. Carroll V. Hill and Associates, Planning Consultants Columbus, Ohio, p. 10

${ }^{2}$ Candeub, Fleissig, and Associates, Preston County Comprehensive Development Plan, Phase 1-Basic Research, Surveys, and Analysis. Candeub, Fleissig, and Associates, Planning and Community Development Consultants, Columbus, Ohio, 1968

${ }^{3}$ Monongalia County Comprehensive Plan, op. cit., p. 241.
Land use for Preston County can be summarized as follows: ${ }^{4}$

$\begin{array}{lc}\text { Developed } & 10,690 \text { acres or } 2.58 \% \\ \text { Cropland, pasture } & 101,300 \text { acres or } 24.53 \% \\ \text { Woodland } & 243,571 \text { acres or } 59.00 \% \\ \text { Mineral Extraction } & 3,500 \text { acres or } 0.84 \% \\ \text { Openspace (recreation, } & \\ \quad \text { cemeteries) } & 32,624 \text { acres or } 7.90 \% \\ \text { Other } & 21,115 \text { acres or } 5.15 \% \\ \quad \text { Total } & 412,800 \quad 100.00 \%\end{array}$

The northern section of Preston County can be broadly characterized as a dairy and beef cattle farming area with some coal mining activity.

\section{Population}

West Virginia's population declined by 7.2 per cent between 1950 and 1960. Between 1960 and 1970 it decreased by 6.2 per cent. Monongalia's population rose by 14.6 per cent during the last decade. Table 1 gives population data for the area. Morgantown and Star City were excluded from the districts intersected by the study area because this study deals only with non-municipal properties.

\section{Corridor E Highway}

Corridor E is a part of the Appalachian Development Highway Systemcovering 2,700 miles in ten states-being built to help eliminate the Appalachian Area's isolation and stimulate economic development. Corridor E will join the north-south I-79 at Morgantown and run east to I-70 near Hancock, Maryland. This new highway will open up north central West Virginia to the BaltimoreWashington area.

TABLE 1. POPULATION DATA.

\begin{tabular}{|c|c|c|c|}
\hline & Year & $\begin{array}{l}\text { Monongalia } \\
\text { County }\end{array}$ & $\begin{array}{l}\text { Preston } \\
\text { County }\end{array}$ \\
\hline $\begin{array}{l}\text { Districts Intersected } \\
\text { by Study Area }\end{array}$ & $\begin{array}{l}1960 \\
1970\end{array}$ & $\begin{array}{l}13,537 * \\
16,109 \dagger\end{array}$ & $\begin{array}{l}3,667 \\
3,258\end{array}$ \\
\hline County & $\begin{array}{l}1960 \\
1970\end{array}$ & $\begin{array}{l}55,617 \\
63,714\end{array}$ & $\begin{array}{l}27,233 \\
24,455\end{array}$ \\
\hline
\end{tabular}

*Excludes Morgantown, population 22,487, and Star City, population 1,236. $\dagger$ Excludes Morgantown, population 29,431, and Star City, population 1,312. Source: U.S. Census of Population, 1960 and 1970.

${ }^{4}$ Preston County Comprehensive Plan, op. cit., p. A-6. 
Location of Corridor E was finalized and right-of-way acquisition began in late 1969. As of January, 1973, the status of the 32.5-mile portion of the highway located in West Virginia was as follows: 26.1 miles under construction with right-of-way acquisition underway for the remaining 6.4 miles. Right-ofway acquisition for the Monongalia segments has been underway since 1971 . Most of the earlier contracts awarded were in Preston County, while the later contracts were in Monongalia County.

\section{Analysis of Land Transactions}

Between January 1, 1966 and December 31, 1971 over 1,500 property titles were transferred and recorded in the county courthouses for properties located within the study area. Each transfer was examined for evidence of non-market influences. The concept of a valid sale was one in which money was actually paid for the property transferred and that it was the only consideration of value for the sale of the property. An attempt was made to eliminate sales which might reflect extra-market factors and thus bias the results. The criteria used to eliminate transfers indicative of extra-market behavior included: (a) one-dollar transactions, (b) parent to child transfers, (c) transfers in which the grantor and grantee had the same surname, and (d) transfers in which the West Virginia Department of Highways was the grantee. A total of 1,093 transfers were accepted as valid market sales.

A breakdown of the transfers by location has been used to examine distinct differences existing in segments of the market. The three groups established locate the transactions according to: (a) Subdivision, ${ }^{5}$ (b) Monongalia, that is, in the Monongalia County section of the study area exclusive of the subdivision sales, and (c) Preston, that is, the Preston County portion of the study area. There were no subdivisions in Preston County.

\section{LIMITATION OF ACREAGE AND CONSIDERATION DATA}

Land values in the study area represent a very heterogeneous market. Unlike studies dealing with agricultural land or with county averages the transfers in this study represent all valid land sales in a delineated area for a six-year period. The study area lies in the Appalachian region where great variations in topography exist. Other factors which could cause variations in land prices are the locational and use characteristics of the land sold, which ranged from isolated forest lands to suburban housing developments. An attempt has been made to reduce the variations among properties sold by dividing them into locational groups, acreage groups, comparing values on a per acre basis, removing the influence of

${ }^{5} \mathrm{~A}$ subdivision as used in this study refers to an area for which a separate tax map has been created. In general, subdivisions are areas with a concentration of small parcels of land. buildings, and examining the impact of time on market values. In some instances building a transactions of a particular size or from a specific location the small number of transactions of a particular size or the general situation.

means that the information may not be characteristic of the generaps do not reveal

The reader is cautioned that the means for different groups do not reveal the wide degree of variations that were present in In a later section a model will be developed to simultaneously measure the In a later secturicis on land.

\section{DISTRIBUTION OF TRANSFERS}

Land sales were highly concentrated in the western portion of the study About one-third of all sales in the study occurred in subdivisions (Table 2). There were 26 different rural subdivisions in the study area; some of these were There were 26 differe small concentrations new housing developments or trailer courts and othe of population. In addition to the 369 subdivisions sales, there were another 583 transfers in Monongalia County. Combined, these transactions accounted for 87 per cent of all transfers in the study area. The remaining 141 sales were located in Preston County.

The number of transactions per year in the study area increased slightly for each year between 1966 and 1970 but dropped in 1971 . Fluctuations within the locational groups did not appear to follow any set pattern.

TABLE 2. DISTRIBUTION OF NUMBER OF TRANSFERS BY YEAR AND LOCATION.

\begin{tabular}{|c|c|c|c|c|}
\hline \multirow[b]{2}{*}{ Year } & \multicolumn{4}{|c|}{ Location } \\
\hline & Subdivision & Monongalia & Preston & Study Area \\
\hline 1966 & 45 & 98 & 27 & 170 \\
\hline 1967 & 55 & 90 & 28 & 173 \\
\hline 1968 & 80 & 88 & 22 & 190 \\
\hline 1969 & 62 & 109 & 22 & 193 \\
\hline 1970 & 75 & 101 & 32 & 208 \\
\hline 1971 & 52 & 97 & 10 & 159 \\
\hline Total & 369 & 583 & 141 & 1,093 \\
\hline
\end{tabular}




\section{ACREAGE TRANSFERRED}

Sales involving small acreages made up the majority of all transactions. Over 50 per cent of the sales involved less than one acre of land and 81 per cent involved less than 5 acres (Table 3). Although the small acreage sales comprised the majority of all sales they accounted for a relatively small portion of the total land sold. Transfers of less than 5 acres accounted for only 7.8 per cent of the total acreage sold, while the 29 sales of 100 acres or more accounted for 42 per cent of all land sold. Table 3 also shows the distribution of total acreage transferred by location and size of parcel.

\section{CONSIDERATION}

Real estate sales for all years totaled approximately $\$ 8,664,157$ for the study area with a range from $\$ 30$ to $\$ 350,000$ per transfer and an average consideration of $\$ 7,927$ (Table 4). Sales of less than 5.0 acres accounted for 70.9 per cent of the total consideration paid. Total market consideration for the 369 Subdivision sales nearly equaled that of the 583 Monongalia sales.

Breaking the transfers into different groups according to the amount of consideration gives a more complete picture of the dollar value of most transfers (Table 5). Sales of less than $\$ 5,000$ accounted for more than half of all transactions, however, they accounted for only 12 per cent of the value of all property transferred. The average consideration for sales in the Subdivision, Monongalia, and Preston groups were $\$ 10,567, \$ 7,026$ and $\$ 4,743$, respectively.

\section{PRICE PER ACRE}

To compare market values for different sizes of parcels sold and for parcels in different locations a unit base of price (consideration) per acre was used. Price per acre was derived by dividing the average consideration for a particular location and/or acreage group by the average acreage corresponding to that location and/or acreage group. For sales under one acre, price per acre will be higher than consideration, whereas sales greater than one acre have the opposite relationship.

Various factors influence the price per acre paid for land. The demand for small tracts of land for residential and other uses is often high and thus prices for such parcels are high. Larger tracts of land may include portions that are non-useable, while small parcels may represent choice segments of larger tracts. Buildings and other improvements have a great influence on the price per acre for small parcels while their value is spread out for larger tracts of land.

The average price per acre for different acreage and location groups are given in Table 6. Prices per acre for the study area decreased most as acreage per transfer increased from 0.1-0.9 to 2.04.9. Parcels of similar sizes commanded a considerably greater price if located in a subdivision and those in Monongalia were higher than for similar size parcels in Preston County.
TABLE 3. ACREAGE TRANSFERRED BY SIZE OF PARCEL AND LOCATION.

\begin{tabular}{|c|c|c|c|c|c|}
\hline \multirow{2}{*}{$\begin{array}{l}\text { Size of } \\
\text { Parcel } \\
\text { (acres) }\end{array}$} & & \multicolumn{4}{|c|}{ Location } \\
\hline & & division & galia & Preston & Study \\
\hline \multirow[t]{2}{*}{$0.0-0.9$} & No. of transfers & 323 & 216 & 54 & 593 \\
\hline & Acres per transfer & 0.34 & 0.45 & 0.48 & 0.39 \\
\hline \multirow{4}{*}{$1.0-1.9$} & & & & & \\
\hline & No. of transfers & 35 & 121 & 18 & 174 \\
\hline & Acres per transfer & 1.22 & 1.26 & 1.23 & 1.25 \\
\hline & 10tar actes & & 132.1 & & $21 / .4$ \\
\hline \multirow[t]{3}{*}{$2.0-4.9$} & No. of transfers & 11 & 92 & 16 & 119 \\
\hline & Acres per transfer & 2.94 & 3.04 & 3.72 & 3.12 \\
\hline & Total acres & 32.4 & 279.6 & 59.50 & 371.5 \\
\hline \multirow[t]{3}{*}{$5.0-9.9$} & No. of transfers & 0 & 48 & 7 & 55 \\
\hline & Acres per transfer & & 7.18 & $\begin{array}{r}7.16 \\
501\end{array}$ & $\begin{array}{r}7.17 \\
394.5\end{array}$ \\
\hline & Total acres & & & & 394.5 \\
\hline \multirow[t]{3}{*}{$10.0-24.9$} & No. of transfers & 0 & 33 & 12 & 45 \\
\hline & Acres per transfer & & 15.90 & 18.30 & 16.54 \\
\hline & Total acres & & 524.7 & 219.6 & 744.3 \\
\hline \multirow[t]{3}{*}{$25.0-49.9$} & No. of transfers & 0 & 34 & 3 & 37 \\
\hline & Acres per transfer & & 32.86 & 37.27 & 33.22 \\
\hline & Total acres & & $1,117.3$ & 111.8 & $1,229.1$ \\
\hline \multirow[t]{3}{*}{$50.0-74.9$} & No. of transfers & 0 & 19 & 5 & 24 \\
\hline & Acres per transfer & & 56.90 & 66.12 & 58.82 \\
\hline & Total acres & & $1,081.0$ & 330.6 & $1,411.6$ \\
\hline \multirow[t]{3}{*}{$75.0-99.9$} & No. of transfers & 0 & 9 & 8 & 17 \\
\hline & Acres per transfer & & 86.98 & 87.92 & 87.42 \\
\hline & Total acres & & 782.8 & 703.4 & $1,486.2$ \\
\hline \multirow[t]{3}{*}{100.0 plus } & No. of transfers & 0 & 11 & 18 & 29 \\
\hline & Acres per transfer & & 135.03 & 167.28 & 155.04 \\
\hline & Total acres & & $1,485.3$ & $3,011.0$ & $4,496.3$ \\
\hline \multirow{3}{*}{$\begin{array}{l}\text { All } \\
\text { Acreages }\end{array}$} & No. of transfers & 369 & 583 & 141 & 1,093 \\
\hline & Acres per transfer & 0.50 & 10.06 & 32.16 & 9.68 \\
\hline & Total acres & 184.8 & $5,865.7$ & $4,533.9$ & $10,584.4$ \\
\hline
\end{tabular}




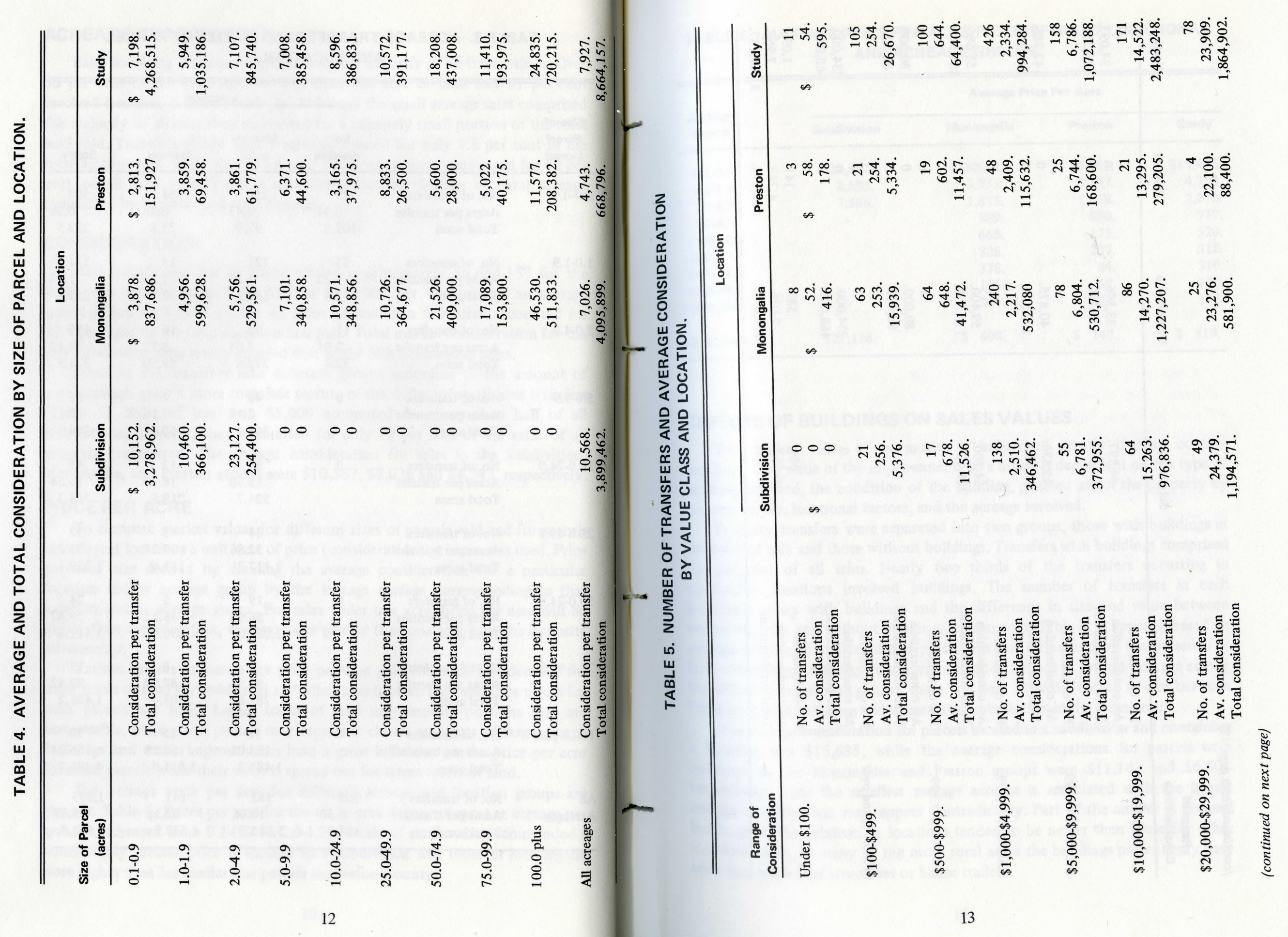


TABLE 6. AVERAGE PRICE PER ACRE FOR DIFFERENT LOCATIONAL AND ACREAGE GROUPS.

\begin{tabular}{ccccr}
\hline \hline \multirow{2}{*}{$\begin{array}{c}\text { Acreage } \\
\text { Group }\end{array}$} & \multicolumn{4}{c}{ Average Price Per Acre } \\
\cline { 2 - 5 } & Subdivision & Monongalia & Preston & Study \\
\hline $0.1-0.9$ & $\$ 29,857$. & $\$ 8,618$. & $\$ 5,861$. & $\$ 18,456$. \\
$1.0-1.9$ & $8,595$. & $3,933$. & $3,137$. & $4,759$. \\
$2.0-4.9$ & $7,866$. & $1,893$. & $1,038$. & $2,278$. \\
$5.0-9.9$ & - & 989. & 890. & 977. \\
$10.0-24.9$ & - & 665. & 173. & 520. \\
$25.0-49.9$ & - & 326. & 237. & 318. \\
$50.0-74.9$ & - & 378. & 84. & 310. \\
$75.0-99.9$ & - & 196. & 57. & 130. \\
100.0 plus & $\$ 21,136$. & $\$ 69$. & 69. & 160. \\
& - & & $\$ 147$. & $\$ 819$. \\
All Acreage & & & & \\
\hline
\end{tabular}

\section{EFFECTS OF BUILDINGS ON SALES VALUES}

The market value of properties is influenced greatly if they contain buildings. The value of the improvements to a buyer is dependent on the type of building involved, the condition of the building, planned use of the property by the new owner, locational factors, and the acreage involved.

Property transfers were separated into two groups, those with buildings at the time of sale and those without buildings. Transfers with buildings comprised 55 per cent of all sales. Nearly two thirds of the transfers occurring in subdivision locations involved buildings. The number of transfers in each locational group with buildings and the difference in size and value between properties with and without buildings are shown in Table 7. It appears, based on average acreage, that size of the parcel was not influenced by the presence or lack of buildings. Although there was a large difference in average acreage among the different locational groups, there was very little difference in size between those sales with buildings and those without buildings in the same group.

The average consideration for parcels located in a subdivision and containing a building was $\$ 15,635$, while the average considerations for parcels with buildings in the Monongalia and Preston groups were $\$ 11,143$ and $\$ 6,501$ respectively. That the smallest average acreage is associated with the largest average consideration may appear contradictory. Part of the answer is because buildings in the subdivision locations tended to be newer than those for other locations. Also, in many of the more rural areas the buildings present may have been non-residential structures or house trailers. 
TABLE 7. EFFECTS OF BUILDINGS ON TRANSFERS.*

\begin{tabular}{llrrrr}
\hline \hline & & \multicolumn{4}{c}{ Location } \\
\cline { 3 - 6 } & & $\begin{array}{c}\text { Subdi- } \\
\text { vision }\end{array}$ & $\begin{array}{c}\text { Monon- } \\
\text { galia }\end{array}$ & Preston & Study \\
\hline $\begin{array}{l}\text { No. of } \\
\text { transfers }\end{array}$ & With bldg. & 229 & 276 & 82 & 587 \\
Av. & Without bldg. & 128 & 298 & 59 & 485 \\
acreage & With bldg. & 0.53 & 9.64 & 34.62 & 9.58 \\
Av. & Without bldg. & 0.45 & 9.68 & 28.73 & 9.56 \\
consideration & With bldg. & $\$ 15,635$. & $\$ 11,143$. & $\$ 6,501$. & $\$ 12,247$. \\
Av. price & Without bldg. & $2,142$. & $3,214$. & $2,300$. & $2,820$. \\
per acre & With bldg. & $\$ 29,500$. & $\$ 1,156$. & $\$ 2,300$. & $\$ 1,278$. \\
\hline
\end{tabular}

*21 transfers were omitted due to a lack of information on the presence of buildings.

Comparing prices on a per acre basis for bare land also reveals the great difference that exists between locations. Lots sold in the subdivision group, without buildings, had an average price equivalent to $\$ 4,760$ per acre. This is fourteen times as great as the average price per acre paid for non-subdivision bare land in the Monongalia group and nearly sixty times as great as the average price per acre in the Preston group. Lots in subdivisions often include clearing, landscaping, and other improvements which are included in the market value of the property.

To gain a better concept of land values, transfers also were grouped by acreages and location with and without buildings as shown in Tables 8 and 9. In general, both tables show a significant decrease in per acre price as size of the parcel increases regardless of the location. Table 8 indicates the decreasing relative importance of buildings as acreage increases. Table 9 and Figure 2 indicate that a high premium exists for small acreage parcels of bare land.

\section{INFLUENCE OF TIME}

Land values in West Virginia have been steadily rising in recent years. The U. S. Department of Agriculture's average farm real estate value per acre index (1967=100) for West Virginia was 96 in March, 1966, and 177 in March, 1972, an increase of 84 per cent. ${ }^{6}$ Land values in the study area showed an even greater increase (Table 10). Several factors may have contributed to this. Much of the area is becoming residential, increasing the value of land suited to this use.

6“"Indexes of Farm Real Estate Values Per Acre, 1912-1972," Farm Real Estate Market Developments, Economic Research Service, USDA, Washington, D.C. Supplement No. 2, June, 1973.

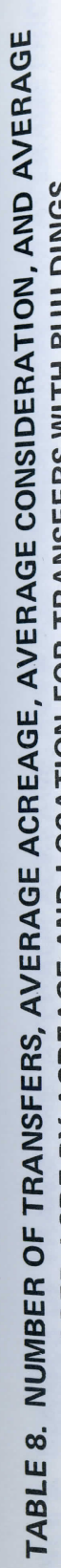

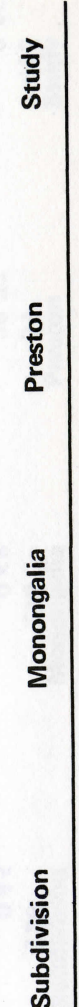

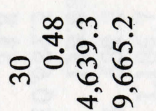$$
\text { a 穴 }
$$

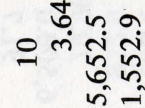

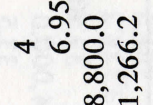

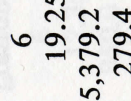$$
\infty
$$$$
\leftrightarrow
$$$$
\infty
$$$$
\text { cs }
$$

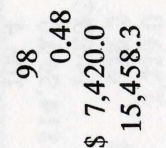

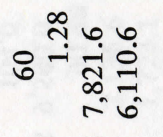$$
\text { \% }
$$

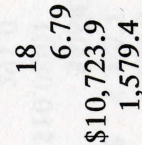

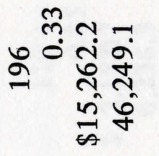$$
\text { ๙ึำ }
$$

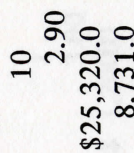

$\circ$
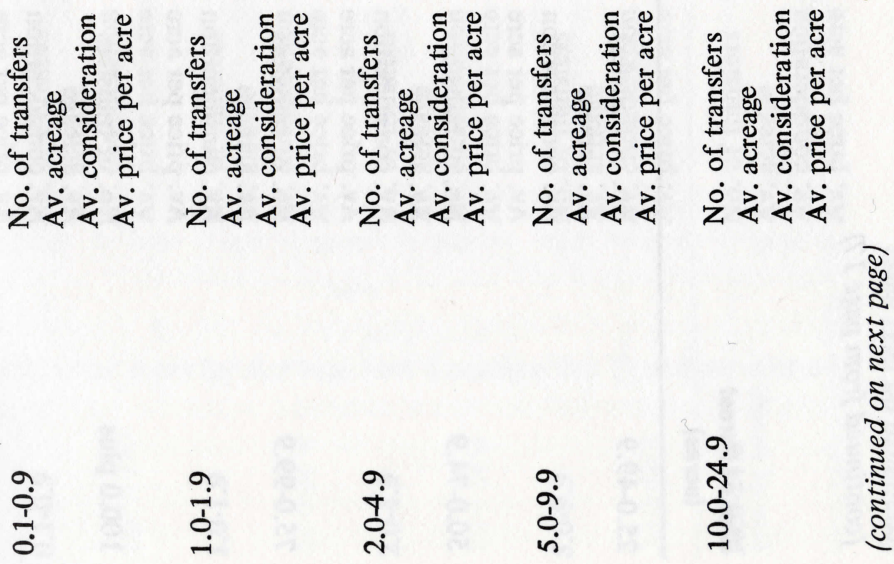


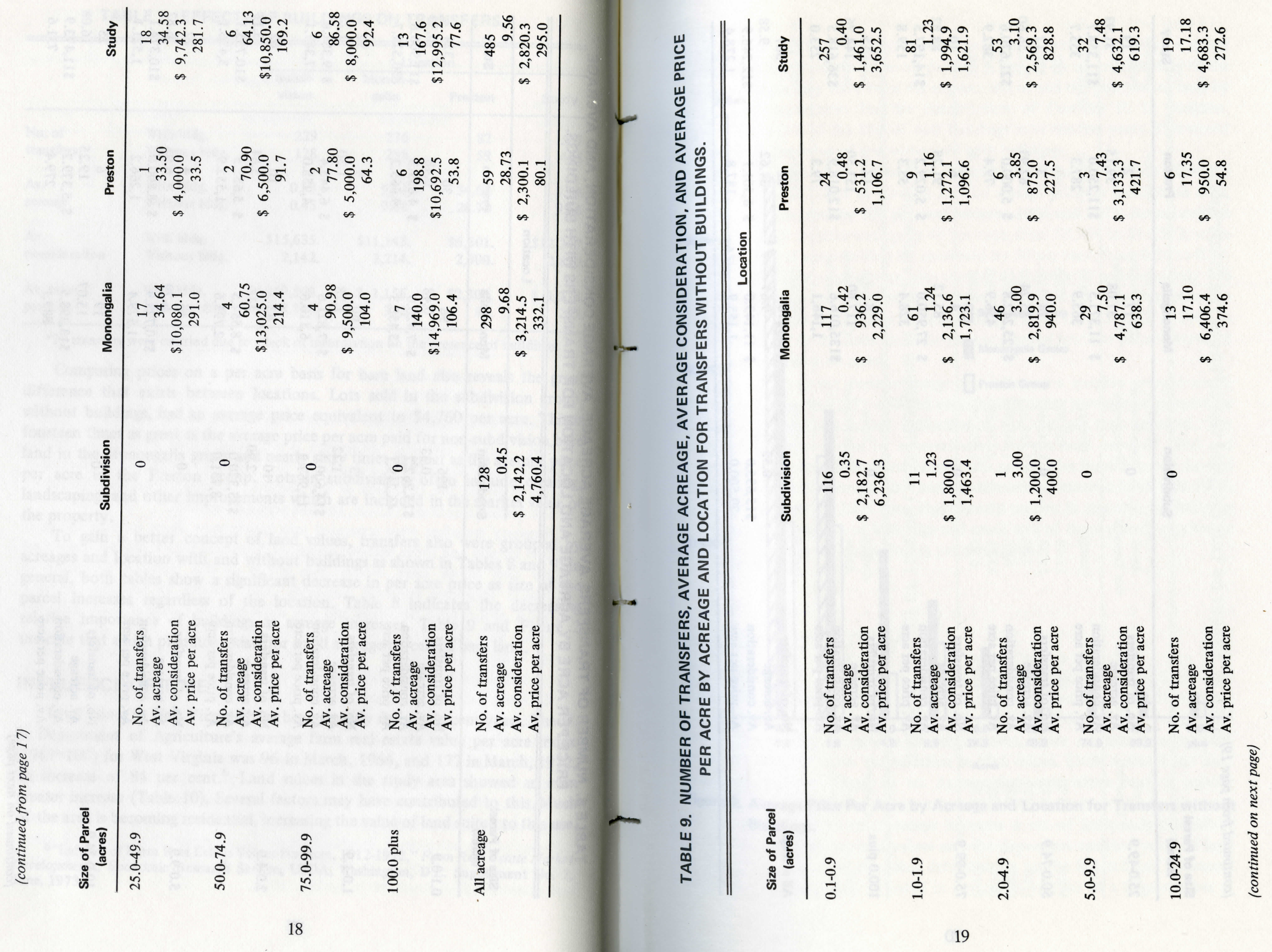




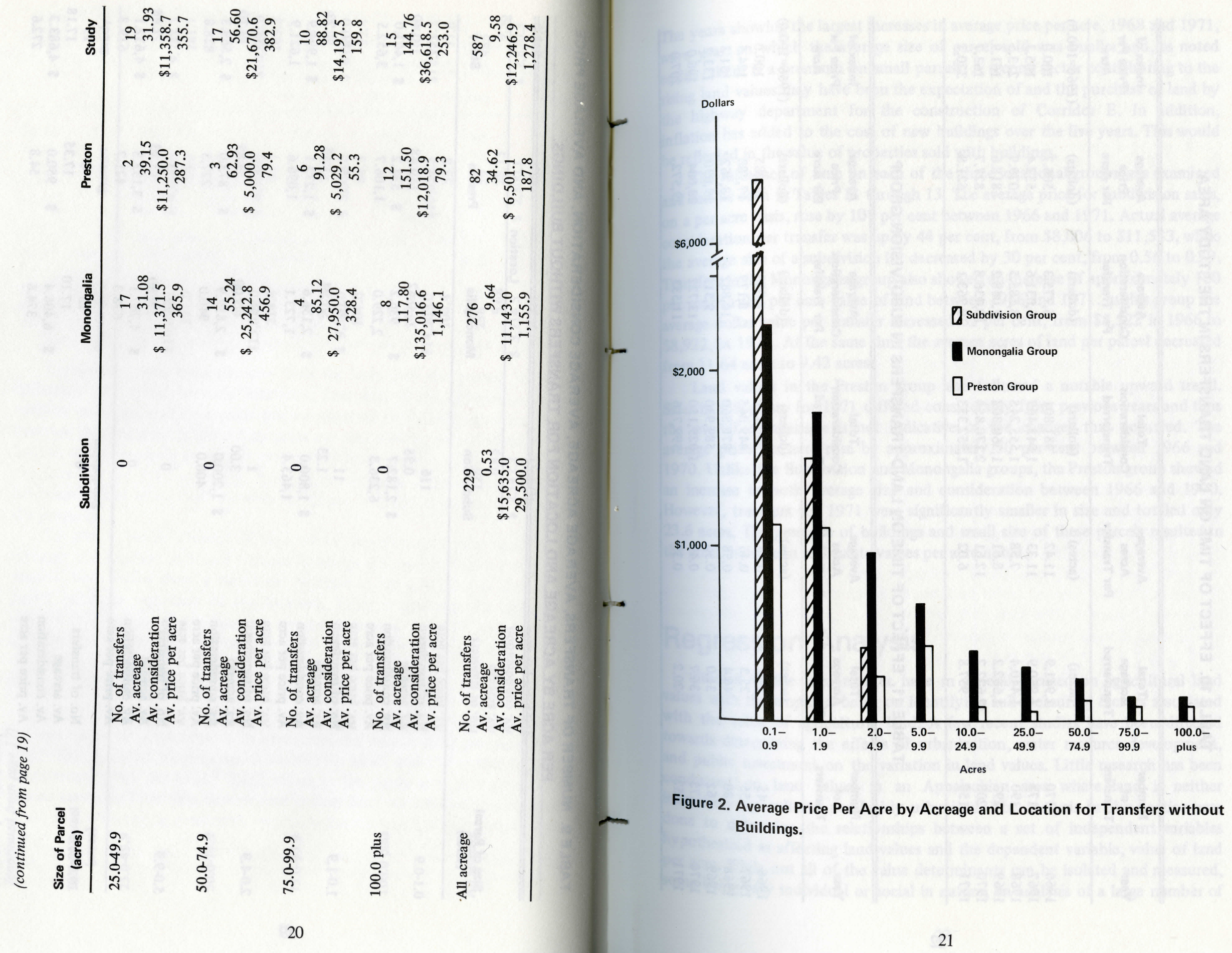




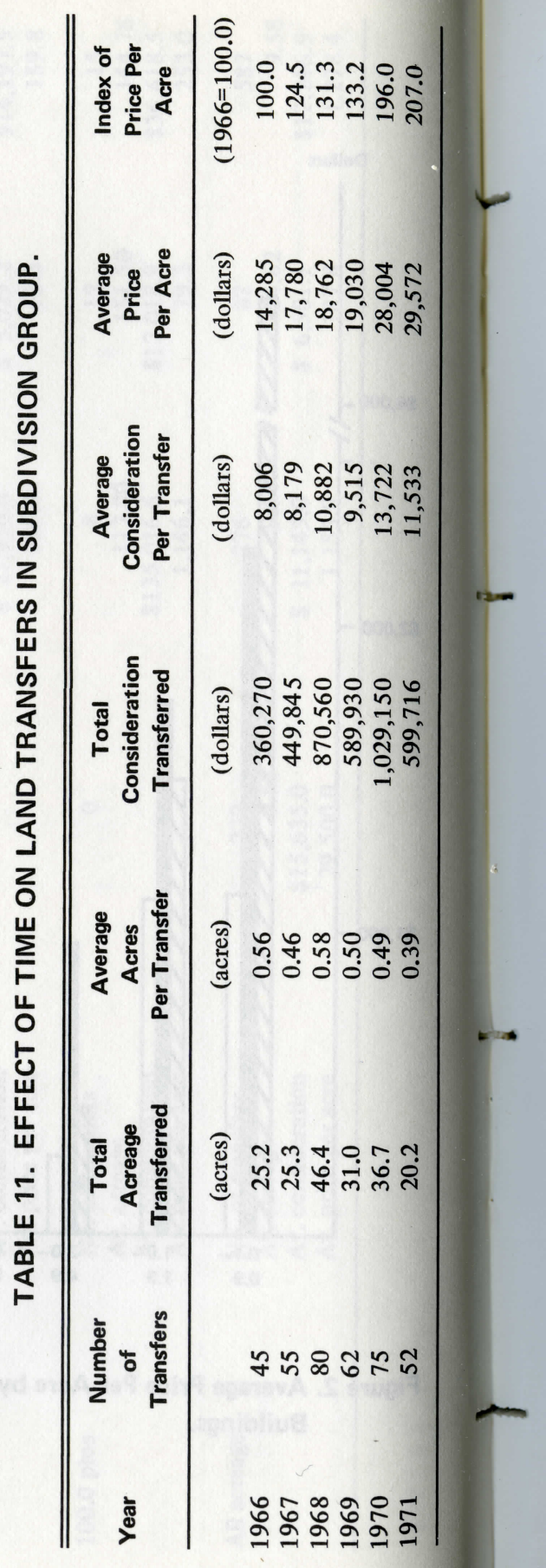

The years showing the largest increases in average price per acre, 1968 and 1971, The years she size of parcel sold was smaller and, as noted were years is a premium on small parcels. A second factor contributing to the earlier, the values may have been the expectation of and the purchase of land by rising lan department for the construction of Corridor E. In addition, the high has added to the cost of new buildings over the five years. This would inflation has in the value of properties sold with buildings.

The influence of time on each of the three locational groups was examined and be seen in Tables 11 through 13. The average price for subdivision sales, and acre basis, rose by 107 per cent between 1966 and 1971. Actual average consideration per transfer was up by 44 per cent, from $\$ 8,006$ to $\$ 11,533$, while conside of a subdivision lot decreased by 30 per cent, from 0.56 to 0.39 . the average size of a subdivision lo also showed an increase of approximately 100 Transfers in the Monong 1966 and 1971. In this group the per cent in the per acre value of transfer increased 62 per cent, from $\$ 5,522$ in 1966 to average dollar value at the same time the acreased from 11.64 acres to 9.42 acres.

Land values in the Preston group also followed a notable upward trend. Sales in this group for 1971 differed considerably from previous years and thus the overall comparison is not indicative of the changes that occurred. The average price per acre rose by approximately 50 per cent between 1966 and 1970. Unlike the Subdivision and Monongalia groups, the Preston group showed an increase in both average size and consideration between 1966 and 1970 . However, transfers for 1971 were significantly smaller in size and totaled only 23.6 acres. The presence of buildings and small size of these parcels resulted in the great increase in real estate values per acre noted.

\section{Regression Analysis}

Studies of the land market have in general focused on agricultural land values with the emphasis being on identifying and measuring factors associated with the value of agricultural land. A few recent studies have been directed towards determining the effects of urbanization, water resource development, and public investment on the variation in land values. Little research has been conducted on land values in an Appalachian area where land is neither intensively agricultural nor highly urbanized. The analysis in this section was done to determine the relationships between a set of independent variables hypothesized as affecting land values and the dependent variable, value of land per acre. While not all of the value determinants can be isolated and measured, some being very individual or social in nature, an analysis of a large number of 
actual real estate market sales should reveal the relation between value and some of the more important of these variables.

The independent variables considered in this study have been organized into three groups to clarify and provide a convenient frame of reference (1) those associated with the soil and physical land characteristics, (2) those associated with the location of the property, and (3) those characteristics associated with the transfer of the individual property.

\section{THE VARIABLES}

The following is a description of the variables hypothesized to be related to land values. The dependent variable Y, price per acre, was derived by dividing the consideration for each transfer by the acreage involved and therefore includes the value of land, buildings, and improvements. A complete list of the variables used in the analysis is presented in Appendix A.

Factors Associated with the Soil or Physical Features. Land quality or characteristics of the soil and the physical features of the land were hypothesized to be related to the market value of land. Data on the land characteristics of each parcel were obtained from aerial photographs mapped to show different soil and physical features. The maps were made available by the Soil Conservation Service. Adequately measuring the physical and soil characteristics of a tract of land in a manner that can be easily coded and analyzed presents certain problems. The attempt here was to determine the predominant or average characteristic for the land parcel. The following variables were compiled as measures of the physical characteristics of the parcel transferred.

Variable $\mathrm{X}_{1}$ was a measure of average slope of a particular property. The greater slopes were expected to be more difficult and costly for residential development, though in some specialized locations a property with a greater slope may be desirable in terms of aesthetic value, i.e. view of the surrounding countryside. In general, it is expected that land with a lesser slope would command a premium. Distribution of transfers by average slope is listed below.

0-8\% slope, 302 transfers (28.01\%)

$8-15 \%$ slope, 452 transfers $(41.93 \%)$

$15-25 \%$ slope, 230 transfers $(21.34 \%)$

$25-35 \%$ slope, 70 transfers ( $6.49 \%)$

$35 \%$ slope, 24 transfers ( $2.23 \%$ )

${ }^{7}$ The classification system is similar to one used by Downing and Jansma. See Roger $\mathrm{H}$. Downing and Dean J. Jansma, The Economic Impact of Public Investment on Property Values in York County, 1950-1965. Research Publication No. 61. University Park: The Institute for Research on Land and Water Resources, Pennsylvania State University, April,
1970 . 
Variable $\mathrm{X}_{2}$ was a measure of land quality, the land capability classification of the Soil Conservation Service, which groups soils to show their suitability for most kinds of farming. Capability classes range from I to VII and denote decreasing land quality. It was expected that this variable would be negatively related to land values. Distribution of transfers by the dominant land capability class for the parcel is shown in Table 14.

Variable $\mathrm{X}_{3}$ was a measure of the soil limitation for sewage disposal (filter field method). This index was developed by officials of the Monongalia County Soil Conservation Service. The degree of limitation-slight, moderate, or severe-indicates the severity of problems expected to be encountered for the specified use. Considered in arriving at this index were such characteristics of the soil as slope, depth to bedrock, permeability, depth to water table, and liklihood of flooding. Limitation of the soil for building construction purposes also was considered as a variable but the high degree of correlation to variable $\mathrm{X}_{3}$ ( $\mathrm{r}$ value of .93) made the measurement redundant as a separate variable.

Variable $\mathrm{X}_{4}$ was a measure of land use in a general sense. Three categories of land use were recorded-cleared (meadows, pastures, and open spaces), forested, and other, which referred primarily to residential use. If the parcel was two acres or less and contained buildings it was coded as other. If the parcel contained buildings and was over two acres in size or if there were no buildings, it was coded as either cleared or forested. Variable $\mathrm{X}_{4}$ was used as a classification (Dummy) variable. ${ }^{8}$

Factors Associated with the Location of the Property. Variables $\mathrm{X}_{5}$ through $\mathrm{X}_{11}$ were used to evaluate some of the locational characteristics of a land parcel. It would seem logical that the proximity of a land parcel to an urban area, the availability of public utilities, or the amount of development would, all other things equal, influence the price at which land would sell. Population density also reflects the demand for land for non-farm activities and would be expected to show a positive relationship to land values.

Variable $\mathrm{X}_{5}$ was used to designate the county in which the property was located and was a classification variable. Because Monongalia County is a more

8 Classification variables contain information where the variation is between discrete groups and not a meaningful numerical scale. Variable $\mathrm{X}_{4}$ is such a variable that contained three classes-cleared land, forested land and other land. The method used to handle classification variables in regression is to generate dummy variables, i.e. assign values of 0 's 1 's or -1 's for each class that makes the sum of observations of each dummy variable equal to zero. The number of dummy variables used in the regression equation is one less than the number of classes. The matrix below shows the values for the dummy is one less than the be created for this example.

$\begin{array}{lc}\text { Class } & \text { Dummy } 1 \\ \text { Cleared } & 1 \\ \text { Forested } & 0 \\ \text { Other } & -1\end{array}$

Dummy 2
0
1
-1

TABLE 14. DISTRIBUTION OF TRANSFERS BY CAPABILITY CLASS OF THE LAND.

\begin{tabular}{lccccccr}
\hline & I & II & III & IV & V & VI & VII \\
\hline Number & 2 & 256 & 379 & 175 & 2 & 129 & 135 \\
Percentage & 0.19 & 23.74 & 35.15 & 16.24 & 0.19 & 11.96 & 12.53 \\
\hline
\end{tabular}

urban area and Preston County is more rural it would be expected that land located in Monongalia would command a higher price.

Variable $\mathrm{X}_{6}$ was the driving distance from the land parcel to downtown Morgantown, measured in two-mile intervals. Parcels located the greatest distance from Morgantown may have closer ties to another city but Morgantown is the principal urban center for the majority of transfers and distance from it would be expected to be related to value of land with an inverse relationship.

Variable $\mathrm{X}_{7}$ indicated the direct distance to the nearest Corridor E proposed interchange measured in concentric circles of one-mile intervals. Highway interchange areas are often centers of economic development and it was hypothesized that anticipation of the opening of Corridor E might positively influenced the value of land close to the interchange.

Variable $\mathrm{X}_{8}$ was designed to measure the relative difference in value for properties located along different types of roads. This variable was a classification variable with four categories: (a) located along a major route, (b) located along a paved secondary road, (c) located along a gravel road, and (d) located along a street, i.e. in a subdivision or row of houses. Distribution of transfers by road type are: Major route, 178; Paved secondary, 108; Gravel road, 396; Street, 396. It was expected that there would be a positive relationship between the better roads and the value of land.

Variable $\mathrm{X}_{9}$ indicated which properties have public water available to them. It was expected that this service would be desirable and positively related to the value of rural properties. By coincidence there were 539 transfers with public water available and 539 transfers without water at the time of sale.

Variable $\mathrm{X}_{10}$ was used to measure the locational advantage, if any, of the land parcel being in a subdivision. This also is a classification variable with 366 transfers occurring in subdivisions and 712 transfers outside of subdivisions.

Variable $\mathrm{X}_{11}$ indicated the number of parcels in a particular block, each block being composed of or equal in size to a tax map of 3.9 square miles. It was believed that the number of parcels per block would indicate the amount of development and in a sense the population density of a specific area. The number of land transfers that occurred per block was highly correlated with the number of parcels of land in a block ( $\mathrm{r}$ of .941) and thus $\mathrm{X}_{11}$ also is a measure of the demand for land in a specific area. 
Factors Associated with Transfer Characteristics. The last set of factors hypothesized to be related to land values was composed of characteristics associated with the individual transfer. The first of these, Variable $\mathrm{X}_{12}$, was included to measure the general relation between time of sale and price of the property. An index of one to six was used for the year of sale ranging from 1966 to 1971.

Variable $\mathrm{X}_{13}$ was the number of acres transferred, measured to one decimal place. Small tracts usually reflect a more intensive type of land use and commonly sell for a higher price per acre than large tracts. There may also be a greater demand for smaller tracts because more people are in a financial position to buy them and also they may be closer to a city and are purchased for home sites.

Variable $\mathrm{X}_{14}$ indicated how the property was classified for tax purposes before it was sold and thus if the property was occupied by the grantor at the time of sale. A property not occupied by the owner may indicate it was being held by a speculator and this may be related to the sales value.

Variable $\mathrm{X}_{15}$ was the amount of road frontage on a particular tract. To allow for the difference in size of tract, this was put in terms of feet of road frontage per acre.

Variable $\mathrm{X}_{16}$ was an interaction variable created by multiplying Variable $\mathrm{X}_{12}$, year of sale, by Variable $\mathrm{X}_{7}$, distance to interchange. It was hypothesized that distance to interchange would be more important in the later years.

\section{CORRELATIONS}

Correlation is a measure of the mutual relationship between two variables. The correlation coefficient $r$ is a measure of the degree of closeness of the linear relationship between the two variables. It should be noted that (a) $r$ is a pure number without units or dimensions and $(\mathrm{b}) \mathrm{r}$ always lies between -1 and +1 . Positive values of $r$ indicate that $X_{1}$ and $X_{2}$ tend to increase together; when $r$ is negative, they tend to vary inversely. The statistical significance of $r$ shows the probability that a correlation coefficient as large or larger than the one calculated would have occurred by chance were the variables truly independent.

Table 15 gives the simple correlation coefficients for the variables discussed and price per acre for each class of property. Few of the variables showed very strong linear relations to the price per acre for the property. Variables measuring characteristics of the soil and topography of the tract of land sold seemed to show the least linear relations to price per acre. Variables associated with locational and transfer characteristics tended to show a significant and stronger linear relation than the physical variables. A complete matrix of the simple correlation coefficients for all transfers is presented in Appendix B.
TABLE 15. CORRELATION COEFFICIENTS BETWEEN PRICE PER ACRE TABLE TH INDEPENDENT VARIABLES USED IN LAND MARKET MODELS

\begin{tabular}{|c|c|c|c|c|}
\hline \multirow{2}{*}{ Independent Variable } & \multicolumn{4}{|c|}{ Price Per Acre ${ }^{\mathbf{b}}$} \\
\hline & Class I & Class II & Class III & Class IV \\
\hline $\begin{array}{ll}\mathrm{X}_{1} & \text { Slope } \\
\mathrm{X}_{2} & \text { Capability Class }\end{array}$ & $\begin{array}{l}0.043 \\
0.091 *\end{array}$ & $\begin{array}{r}0.026 \\
-0.022\end{array}$ & $\begin{array}{l}0.201^{* *} \\
-0.125\end{array}$ & $\begin{array}{l}0.007 \\
0.095\end{array}$ \\
\hline $\mathrm{X}_{2}$ Sewage Limitation & -0.069 & $-0.217 * * *$ & -0.039 & -0.084 \\
\hline $\mathrm{X}_{4}$ Land Use & 0.070 & 0.000 & -0.075 & $-0.134^{*}$ \\
\hline $\mathrm{X}_{5}$ County $^{\mathrm{a}}$ & $-0.128 * *$ & $-0.168^{* * *}$ & $-0.194 * *$ & $-0.232 * * *$ \\
\hline $\mathrm{X}_{6}$ Distance to Morgantown & -0.174 & $-0.303 * * *$ & $-0.183 * *$ & $-0.251 * * *$ \\
\hline $\mathrm{X}_{7}$ Distance to Interchange & -0.038 & -0.072 & $-0.192 * *$ & -0.116 \\
\hline $\mathrm{X}_{8}$ Type of Roada & $0.212^{* * *}$ & $0.353^{* * *}$ & $0.232 * * *$ & $0.473 * * *$ \\
\hline X9 Public Water & $0.301^{* * *}$ & $0.309 * * *$ & 0.505 & $0.393 * * *$ \\
\hline $\mathrm{X}_{10}$ In a Subdivision ${ }^{\mathrm{a}}$ & $0.384 * * *$ & $0.465 * * *$ & -0.018 & $0.575 * * *$ \\
\hline $\mathrm{X}_{11}$ Number of Parcels & $0.348 * * *$ & $0.419 * * *$ & $0.499 * * *$ & $0.410 * * *$ \\
\hline $\mathrm{X}_{12}$ Year of Transfer & 0.029 & $0.184 * * *$ & 0.118 & $0.202 * * *$ \\
\hline $\mathrm{X}_{13}$ Acres & $-0.270 * * *$ & $-0.470 * * *$ & $-0.267^{* * *}$ & $-0.309 * * *$ \\
\hline $\mathrm{X}_{14}$ Grantor Tax Class ${ }^{\mathrm{a}}$ & 0.009 & $-0.194 * * *$ & 0.011 & -0.083 \\
\hline $\mathrm{X}_{15}$ Highway Frontage & $0.098^{*}$ & $0.381 * * *$ & $0.273^{* * *}$ & $0.233^{* * *}$ \\
\hline $\mathrm{x}_{16} \mathrm{x}_{7} \times \mathrm{x}_{12}$ & -0.001 & 0.071 & -0.012 & -0.001 \\
\hline
\end{tabular}

*** Statistically significant at the 1 per cent probability level.

**Statistically significant at the 5 per cent probability level.

*Statistically significant at the 10 per cent probability level.

${ }^{\mathrm{a}}$ These variables are classification variables. The correlation coefficients presented here are uncorrected for this difference.

$\mathrm{b}_{\mathrm{C}}$ lass I are properties of two acres or less with no buildings,

Class II are those of two acres or less with buildings,

Class III are those with over two acres with no buildings, and

Class IV are those of over two acres with buildings.

\section{THE MULTIPLE REGRESSION MODELS}

Whereas correlation measures a co-relation, a joint property of two variables, regression deals primarily with the means of one variable and how its values are influenced by another variable. The principle of least squares is used in fitting a linear model to the data. The model is of the general form

$$
\mathrm{E}(\mathrm{Y})=\mathrm{B}_{0}+\mathrm{B}_{1} \mathrm{X}_{1}+\mathrm{B}_{2} \mathrm{X}_{2}+\ldots+\mathrm{B}_{\mathrm{n}} \mathrm{X}_{\mathrm{n}}
$$

where $E(Y)$ means the "expected value of $Y$," where $Y$ is a dependent variable and the $X$ 's are the independent variables. The $B_{1}$ are known as "partial regression coefficients" and they indicate the effects of the independent variables on the dependent variable. Thus, $B_{1}$ measures the average or expected change in $Y$ when $X_{1}$ increases by 1 unit, all other $X$ 's remaining unchanged. In multiple regression, the value of any regression coefficient depends on the other 
variable included in the regression. A t-test is used to test for the statistical significance of a partial regression coefficient.

The "coefficient of determination," $\mathrm{R}^{2}$, is a measure of the amount of variation in $\mathrm{Y}$ explained by all of the independent variables used. $\mathrm{R}^{2}$ will indicate the proportion or per cent of variation in price per acre that can be explained by the regression model. Multiple correlation coefficients are tested for significance by $\mathrm{F}$ tests.

Standard partial regression coefficients are used to indicate the relative importance of different variables. The standard partial regression coefficients are the partial regression coefficients when each variable is in a standard measure, i.e., is a deviation from the mean in units of its standard deviation. Since each standard B is independent of the original units of measurement, a ranking of these coefficients (ignoring sign) indicates the relative importance of the independent variables involved.

Trial equations using all the variables were derived and examined for each class of property. Based on this evaluation certain changes were made in the model. Since $\mathrm{B}_{1}$ indicates how $\mathrm{Y}$ would be expected to alter when $\mathrm{X}$ is varied, holding all other factors fixed, autocorrelation would reduce the equation's value as an estimate of the relative significance of the different variables. Autocorrelation between $\mathrm{X}_{1}$, slope of the land, and $\mathrm{X}_{2}$, land capability index, was quite high. For this reason $X_{1}$ was deleted even though it may have an important relationship to the dependent variable.

The manner in which the data for variable $\mathrm{X}_{4}$, land use, was coded resulted in Class II properties all having the same value for this variable and therefore variable $\mathrm{X}_{4}$ was dropped from the Class II model. Variable $\mathrm{X}_{4}$ was then used only to indicate if a difference existed between cleared and forested land values.

$A$ very high correlation was found between county, $\mathrm{X}_{5}$, and distance to Morgantown, $X_{6}$. Since public water systems and subdivisions were found in only one county, Monongalia, variable $\mathrm{X}_{5}$ was deleted and variable $\mathrm{X}_{6}$ was kept.

Variable $X_{7}$, distance to nearest Corridor $E$ interchange, was not significant for any class of property in the trial equations and thus was deleted. From personal observations and public notices it was known that a large shopping mall, a 200-room motel, some warehouse facilities, and other developments were planned near the Morgantown Corridor E interchange. Also, grantee names indicated that some of the purchases near interchanges were business oriented. Either these purchases near the interchanges did not sell for higher prices or they were too limited to the Morgantown interchanges to be statistically significant.

Trial equations indicated that the primary differences due to type of road, variable $\mathrm{X}_{8}$, arose between the non-paved roads and the other three classes of roads. To make this variable easier to evaluate it was converted to paved versus non-paved roads.
Variable $\mathrm{X}_{14}$, grantor tax class, had to be dropped because approximately one-fifth of the cases did not have values present for this variable. Variable $\mathrm{X}_{16}$, year by distance to interchange, was dropped because it was not significant in any of the trial equations.

\section{Regression Results}

Since the purpose of this analysis was to examine the relationships of various factors on the market price of properties, and since considerable difference in types of properties existed, all properties were divided into four classes to reduce the variations and examine the different relationships. Class I properties were tracts less than or equal to two acres and on which there were no buildings at the time of transfer. Class II properties were tracts less than or equal to two acres and on which there were buildings at the time of transfer. Class III properties were tracts of more than two acres on which there were no buildings and Class IV were tracts greater than two acres with buildings present at the time of sale. The number of valid transfers in the analysis for each of the four classes were: Class I, 347; Class II, 423; Class III, 135; and Class IV, 159. Transfers for less than 100 dollars were deleted from this analysis because it is questionable whether they are valid market transfers.

The average price per acre for the different classes of properties are: Class I, \$4,358; Class II, \$34,040; Class III, \$571; and Class IV, $\$ 1,561$. The partia regression coefficients, $t$-values, and standard partial regression coefficients for each class of property are presented in Table 16. All equations had F-values significant at the 0.0001 level. The coefficients of determination, $\mathrm{R}^{2}, \mathrm{~s}$, for Classes I through IV were $0.216,0.394,0.431$ and 0.537 , respectively.

The following examination of the models is made on a variable by variable basis across the different classes of properties. Variable $\mathrm{X}_{2}$, land capability class, was significant only in the Class II model. Coefficient signs in Class I and IV did not agree with a prior reasoning, that is, that the better quality land would be worth more, all other things being equal. A partial explanation for this may be that the lower land classes, having greater slopes, have greater aesthetic value, but since the coefficients were not statistically significant, these results could have been erroneous.

Variable $\mathrm{X}_{3}$, soil sewage disposal limitations, was significant only for Class II properties. The sign of the coefficient was in the direction hypothesized for al classes.

Cleared land, variable $\mathrm{X}_{4}$, resulted in higher prices for Class III and Class IV parcels. However, Class I (less than or equal to 2.0 acres, no buildings) showed a negative coefficient for cleared land. Since these smaller parcels would typically be used for residences the negative sign probably reflects the desire for trees on residential lots. 


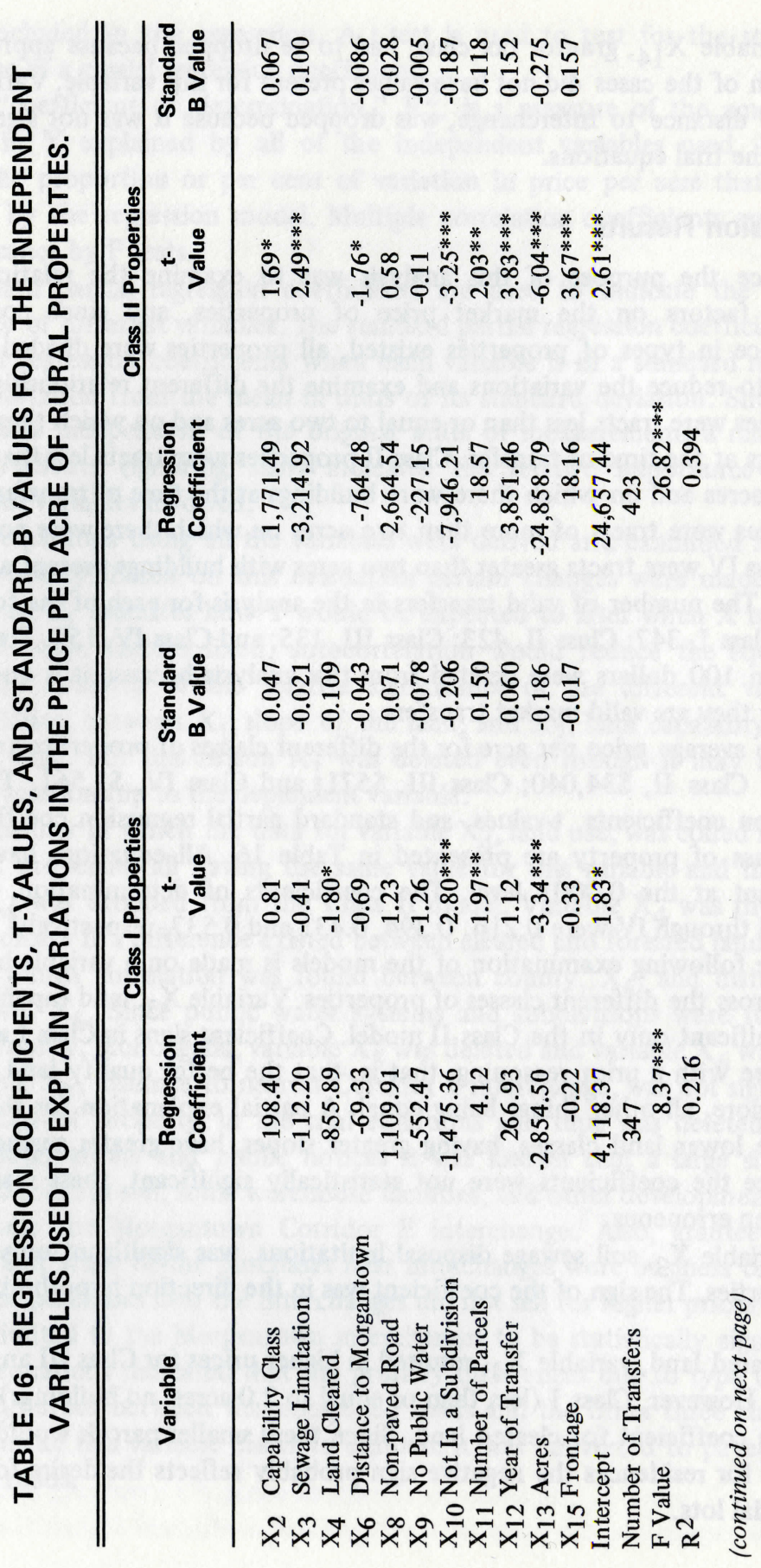

32

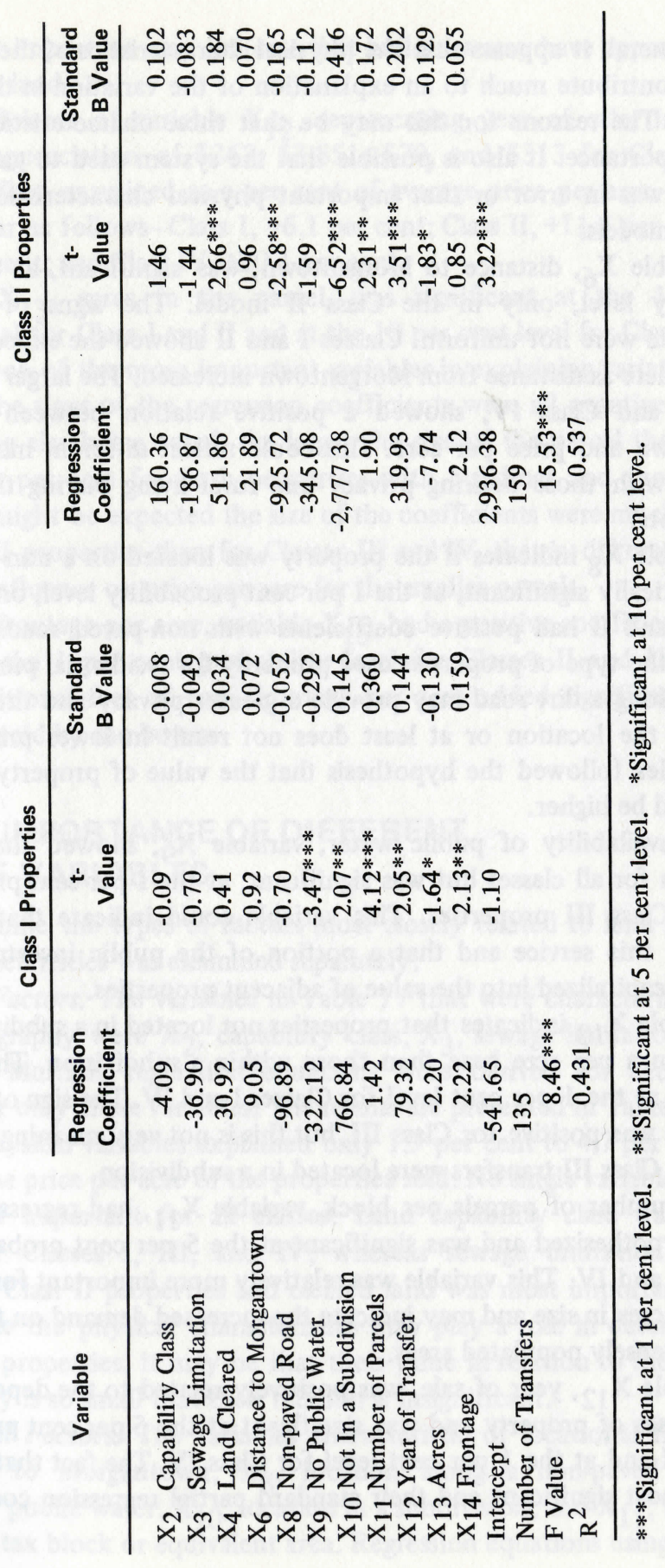

33 
In general, it appears that the physical characteristics of the soil and terrain did not contribute much to an explanation of the variation in the price of rural property. The reasons for this may be that these characteristics were of only minor importance. It also is possible that the system used to gather and record this data was in error or that important physical characteristics were omitted from the models.

Variable $\mathrm{X}_{6}$, distance to Morgantown, was significant, at the 10 per cent probability level, only in the Class II model. The signs of the regression coefficients were not uniform. Classes I and II showed the expected decrease in price per acre as distance from Morgantown increased. The larger parcels of land Class III and Class IV, showed a positive relation between distance from Morgantown and price per acre. This could reflect different motives in buying property with those desiring privacy and rural living buying the larger, more distant plots.

Variable $\mathrm{X}_{8}$ indicates if the property was located on a non-paved road and was statistically significant, at the 1 per cent probability level, only for Class IV. Classes I and II had positive coefficients with non-paved roads. These classes represent the type of properties used primarily for residential purposes and their location along a dirt road may provide a greater privacy and thus be a positive aspect of the location or at least does not result in lower prices. The larger acreage sales followed the hypothesis that the value of property along a paved road would be higher.

The availability of public water, variable $\mathrm{X}_{9}$, showed the hypothesized association for all classes but was significant, at the 1 per cent probability level, only for Class III properties. This variable could indicate that a premium is placed on this service and that a portion of the public investments in water systems is capitalized into the value of adjacent properties.

Variable $\mathrm{X}_{10}$ indicates that properties not located in a subdivision were less valuable on a per acre base than those within a subdivision. This variable was significant at the 1 per cent level for Classes I and IV. The sign of the regression coefficient was positive for Class III, but this is not very meaningful as only two of the 135 Class III transfers were located in a subdivision.

The number of parcels per block, variable $X_{11}$, had regression coefficient signs as hypothesized and was significant at the 5 per cent probability level for Classes III and IV. This variable was relatively more important for the parcels of over two acres in size and may indicate the increased demand on these parcels in the more densely populated areas.

Variable $\mathrm{X}_{12}$, year of sale, was positively related to the dependent variable for all classes of property and was significant at the 5 per cent probability level for Class II and at the 1 per cent level for Class IV. The fact that Classes II and IV were most significant and their standard partial regression coefficients were relatively more important may indicate that buildings may have appreciated at a faster rate than land.

The coefficients of variable $\mathrm{X}_{12}$, representing year of sale, indicate an annual price appreciation of $\$ 267, \$ 3,851, \$ 79$, and $\$ 313$ for Class I to IV respectively. When examined as a per cent of average price per acre the annual increases appear as follows-Class I, +6.1 per cent; Class II, +11.3 per cent; Class III, +13.8 per cent; and Class IV,+20.1 per cent.

Variable $X_{13}$, acres in the parcel, was significant at the 1 per cent probability level for Class I and II and at the 10 per cent level for Classes III and IV. This was one of the more important variables in explaining variations in per acre values. The signs of the regression coefficients were all negative indicating that, everything else being equal, the larger the size of the parcel the lower the expected price per acre for both properties with buildings and those without buildings. As might be expected the size of the coefficients were much larger for Classes I and II properties than for Classes III and IV, that is, differences in size had a greater influence on price per acre for the smaller parcels.

Highway frontage per acre, variable $\mathrm{X}_{15}$, had a positive coefficient that was significant at the 1 per cent probability level for Classes II and III. In these equations additional feet of road frontage per acre added significantly to the price per acre paid by the buyer.

\section{RELATIVE IMPORTANCE OF DIFFERENT GROUPS OF VARIABLES}

To determine the types of factors most closely related to land prices each group of characteristics was examined separately.

Physical Factors. The variables in Table 17 that were characteristics of the soil and topography were $X_{2}$, capability class, $X_{3}$, sewage limitation, and $X_{4}$, cleared land. Multiple regression equations were derived for each class of property using only these variables. The results are presented in Table 17. Taken alone these physical variables explained only 1.9 per cent to 4.7 per cent of the variation in the price per acre of the properties sold. No single variable stood out as being most important for all classes. Land capability class was relatively important for Classes I, III, and IV, whereas sewage limitation was more important on Class II properties and cleared land was most important on Class IV sales. While the physical characteristics may play a role in determining the price of rural properties, it may be that their value in relation to the total price of the property is so small that their relation is insignificant.

Locational Factors. The variables characteristic of locational factors were $\mathrm{X}_{6}$, distance to Morgantown, $\mathrm{X}_{8}$, location along a non-paved road, $\mathrm{X}_{9}$, availability of public water, $X_{10}$, location in a subdivision, and $X_{11}$, the number of parcels per tax block or equivalent area. Regression equations using only these 


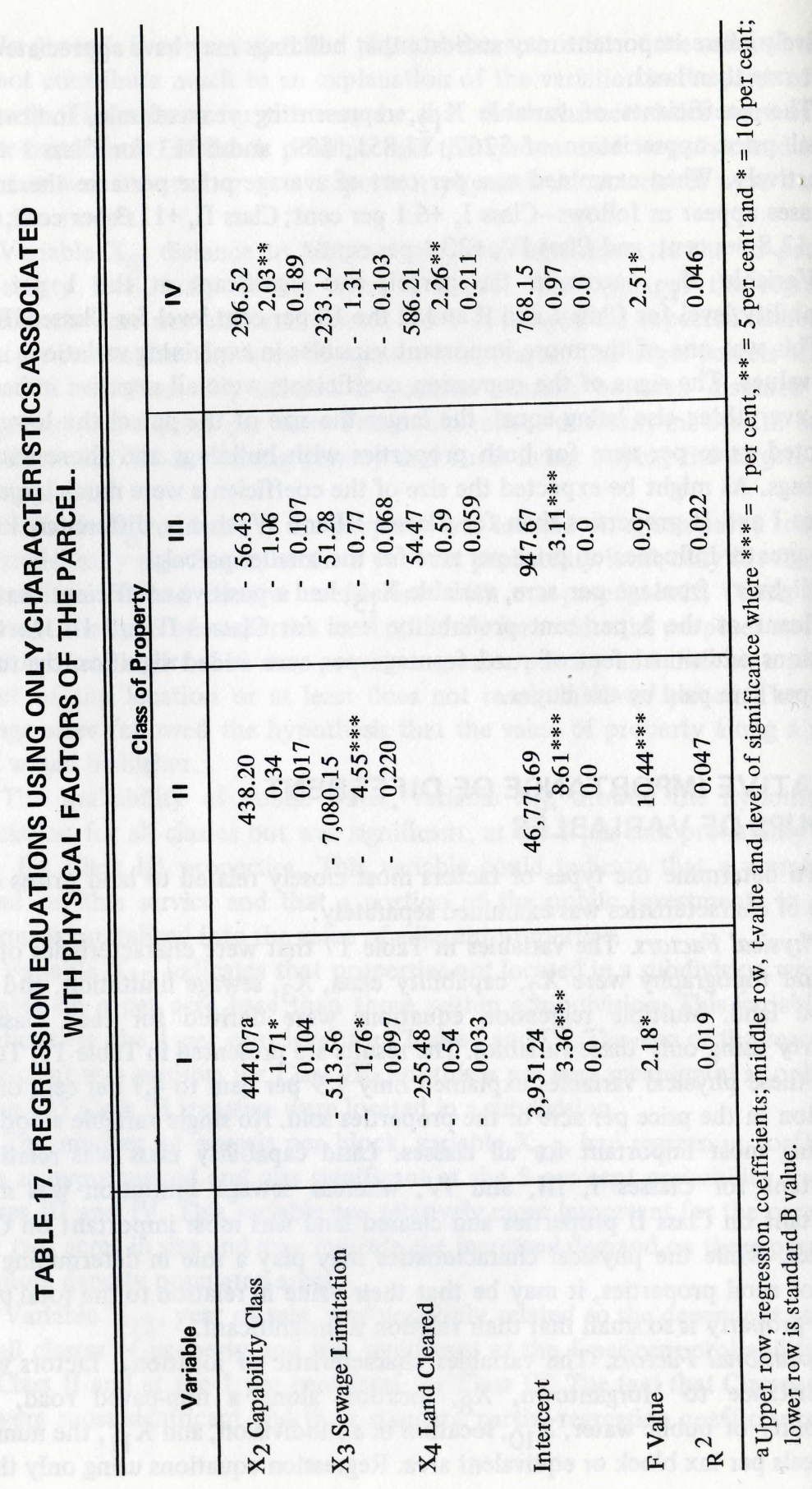

variables are presented in Table 18. Used alone the locational factors explained ver cent and 44.9 per cent of the variation in price per acre of between 17.5 per cent and 44.9 per cent of the variation in price per acre different properties. The availability of public water, remaining equal, may add on the average between $\$ 375$ and $\$ 850$ to the value of parcel of bare land. Another locational factor that was highly significant in a parce variation in rural property values was whether the property was located in a subdivision or not. For example, Class I properties or bare land less located size would be expected to sell forproximately than or equated in a subdivision, the other (The number of different parcels per a given unit area was significant for Class II, III, and IV properties. The larger number of parcels must be indicative of greater development and demand for more intensive land use.

Transfer Factors. The third group of factors were unrelated to physical or locational characteristics and were termed characteristics associated with the transfer. Used in the models were $X_{12}$, year of sale, $X_{13}$, acres in the parcel and $\mathrm{X}_{16}$, highway frontage per acre for the parcel sold. Regression equations using only these transfer characteristics are shown in Table 19. The $\mathrm{R}^{2}$ values for this group of factors ranged from .074 to 0.291 . Acreage was the relatively most important factor in all classes. Except for Class I properties, highway frontage and year of sale added to the $\mathrm{R}^{2}$ value and were statistically significant.

\section{Summary and Conclusions}

The purpose of this study was to gain information and knowledge about the organization, structure and performance of the rural land market in a specified area of West Virginia. The study area was one in which (during the time period of the study) a major land use change in the form of the construction of a four-lane limited access highway was begun. The specific objectives were:

(1) To determine the nature of the organizational and operational characteristics of the rural land market in a specified area;

(2) To identify and rank in significance the factors that affect the price of rural real estate;

(3) To establish benchmark data useful in determining and evaluating the impact of Appalachian Corridor E Highway construction on adjacent land values and land use.

Public land records were used to obtain information on all real estate transfers between January 1, 1966 and December 31, 1971 located within approximately two miles of the new Appalachian Corridor E Highway route. All transfers were examined for non-market influences, after which 1,093 transfers 


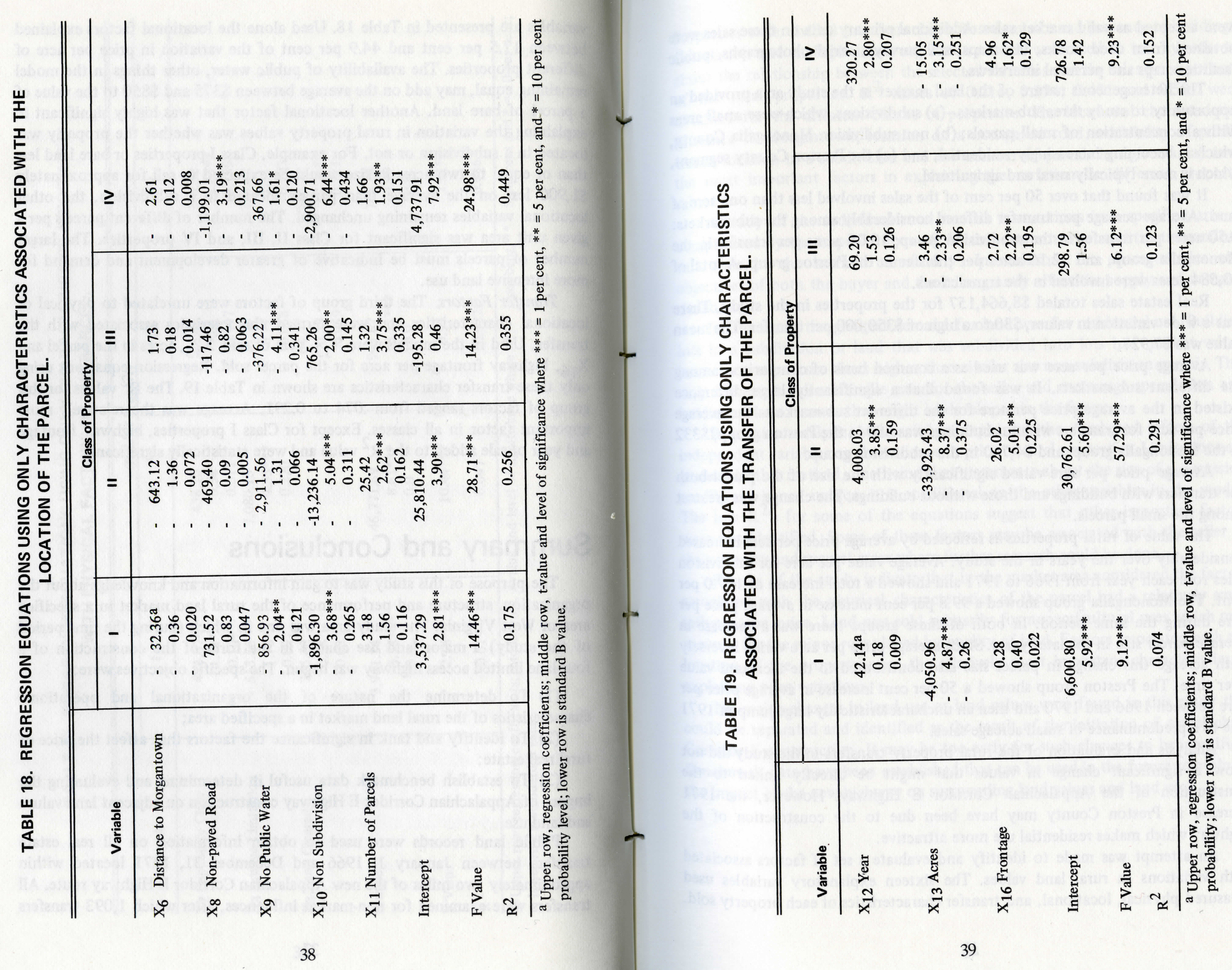


were accepted as valid market sales. Additional primary data on these sales were obtained from deed books, tax maps, soil surveys, aerial photographs, public facilities maps and personal interviews.

The heterogeneous nature of the land market in the study area provided an opportunity to study three sub-markets-(a) subdivisions, which were small areas with a concentration of small parcels; (b) non-subdivision Monongalia County, which is becoming increasingly residential; and (c) the Preston County segment, which is more typically rural and agricultural.

It was found that over 50 per cent of the sales involved less than one acre of land. Average acreage per transfer differed considerably among the sub-markets: 0.50 acres per transfer in the subdivision group, 10.06 acres per transfer in the Monongalia group, and 32.16 acres per transfer in the Preston group. A total of 10,584 acres were involved in the transactions.

Real estate sales totaled $\$ 8,664,157$ for the properties in the study. There was a wide variation in values, $\$ 30$ to a high of $\$ 350,000$ per transfer. The mean value was $\$ 7,927$.

Average price per acre was used as a common basis of comparison among the different sub-markets. It was found that a significantly large difference existed in the average price per acre for the different sub-markets-the average price per acre for transfers without buildings was $\$ 80$ in the Preston group, $\$ 332$ in the Monongalia group, and $\$ 4,760$ in the subdivision group.

Average price per acre varied significantly with the size of the parcel both for transfers with buildings and those without buildings. The change was greatest among the small parcels.

The value of rural properties as reflected by average price per acre increased considerably over the years in the study. Average value per acre for subdivision sales rose each year from 1966 to 1971 and showed a total increase of 107.0 per cent. The Monongalia group showed a 99.8 per cent increase in average price per acre during the same period. In both of these groups there was a decrease in average parcel size in the later years. Since average price per acre varied inversely with acreage this change in parcel size also contributed to the increased value over time. The Preston group showed a 50 per cent increase in average price per acre between 1966 and 1970 and then an uncharacteristically large jump in 1971 due to a predominance of small acreage sales.

Analysis and evaluation of the rural property transfers in the study did not show a significant change in values that might be directly linked to the construction of the Appalachian Corridor E Highway. However, the 1971 increase in Preston County may have been due to the construction of the highwa $\%$ which makes residential use more attractive.

An attempt was made to identify and evaluate a set of factors associated with variations in rural land values. The sixteen explanatory variables used measured physical, locational, and transfer characteristics of each property sold.
Properties were divided into four classes based on size and presence of buildings. Correlation and multiple linear regression models were used to test hypotheses about the relationship between the selected variables and the sales price per acre of the rural properties. $\mathrm{R}^{2}$ values of $0.216,0.394,0.431$ and 0.537 were obtained for the different classes of properties. The locational characteristics (distance to Morgantown, location on a non-paved road, availability of public water, location in a subdivision and the number of parcels in a given area) were the most important factors in explaining the variations in different property values.

A study of the individual rural market transactions in a specified area is complicated by the imperfections of the real estate market and the tremendous variations in the market commodity. In addition, the characteristics and objectives of both the buyer and the seller greatly affect the supply and demand situations.

In this study the greatest demand for land was for residential use. Building lots in a subdivision or land that was subdivided into lots had market values between two and six times higher than similar size non-subdivision parcels. This may represent a considerable gain for the seller and encourage speculation and holding of land in areas that might be developed in the future.

Regression analysis was useful in explaining the combined effects of the independent variables on the variance in price of rural properties. Limitations are present in this method, one being that statements about the size of a regression coefficient is not unique, it is conditional on the other variables in the model. The low $\mathrm{R}^{2}$,s for some of the equations suggest that other important factors were not identified. Some of these factors may be associated with the seller of the property and suggest areas where further research could be done.

Results of the study indicate that in the market area considered the factors associated with the physical characteristics of the parcel had a relatively small influence on price. Land was sold primarily for nonagricultural uses which may account for the minor role played by quality of land. Factors associated with the location of the property were the relatively most important characteristics in explaining price variations.

No major changes in land use or land values were found in this study that could be separated and identified as the result of the initiation of Appalachian Corridor E construction. It may be too early for such changes to be identified. Benchmark data have been established that can be used in the future to evaluate the impact of the new highway on surrounding land values and land use. 


\section{Bibliography}


Abdel-Badie, Farid and Parcher, L. A. Regression and Discriminant Analyses of Agricultural Land Prices, Agricultural Experiment Station Bulletin P-579. Stillwater: Agricultura Experiment Station, Oklahoma State University, 1967.

Aines, Robert O. "Farmland Valuation and Farm Programs," Journal of Farm Economics, Vol. 46, No. 5, Dec. 1964.

Allee, David J. and Harris, Curtis C. Urbanization and Its Effect on Agriculture in Sacramento County, California, Part-2, Giannini Foundation Research Report No. 270. Davis: California Agricultural Experiment Station, University of California, 1963.

Armentrout, W. W. and Haygood, Tyler F. Property Tax Assessment in West Virginia, West Virginia Agricultural Experiment Station Bulletin 358. Morgantown: West Virgini University Agricultural Experiment Station, 1953.

Barlowe, Raleigh. Land Resource Economics. Englewood Cliffs, New Jersey: Prentice Hall, Inc., 1972.

Clawson, Marion. Resources for the Future, Inc. Annual Report 1971. Washington, D.C. Resources for the Future, 1971.

Colyer, Dale and Templeton, Mary. "Analysis of the Market for Rural Land in West Virginia." Research Project Statement, Division of Resource Management, West Virginia University.

Downing, Roger H. and Jansma, Dean J. The Economic Impact of Public Investment on Property Values in York County, 1950-1965. Research Publication Number 61. University Park: The Institute for Research on Land and Water Resources, Pennsylvania State University, April 1970.

Draper, N. R. and Smith, H. Applied Regression Analysis. New York: John Wiley \& Sons, Inc. 1966.

Harris, Karl. Factors That Give Value to Land or Basic Land Values, Arizona Agricultural Experiment Station Bulletin 223. Tucson: Agricultural Experiment Station, University of Arizona, 1949.

Herdt, Robert W. and Cochrane, Willard W. "Farm Land Prices and Farm Technological Advance," Journal of Farm Economics, Vol. 48, No. 2, May 1966.

Keith, John H. Property Tax Assessment Practices. Monerey Park, California: Highland Publishing Co., 1966.

Knetsch, Jack L. "The Influence of Reservoir Projects on Land Values," Journal of Farm Economics, Vol. 46, No. 1, Feb. 1964.

Lindholm, Richard W. Property Taxation - USA. Madison: The University of Wisconsin Press, 1967.

Ottoson, Howard W., Aandahl, Andrew R. and Kristjanson, L. B. “A Method of Farm Real Estate Valuation for Tax Assessment," Journal of Farm Economics, Vol. 37, No. 3, Aug. 1955.

Pendleton, William C. "Economic Effects of Highway Improvement on Land Resources," Modern Land Policy. Englewood Cliffs, New Jersey: Prentice Hall, Inc., 1967.

Pohlman, G. G. Land Classification in West Virginia Based on Use and Agricultural Value, West Virginia Agricultural Experiment Station Bulletin 284. Morgantown: West Virginia University Agricultural Experiment Station, Nov. 1937.
Reinsel, Robert D. and Krenz, Ronald D. Capitalization of Farm Program Benefits into Land Values, Economic Research Service Report 506, Economic Research Service, U. S. Department of Agriculture, Washington, D.C., U. S. Government Printing Office, Oct. 1972.

Renshaw, Edward. "Are Land Prices Too High," Journal of Farm Economics, Vol. 39, No. 2, May 1957.

Salter Jr., Salter A. A Critical Review of Research in Land Economics. Madison: The University of Wisconsin Press, 1967.

Sanders, David B. Transportation and Trade Areas: An Analysis of Morgantown, Fairmont, and Clarksburg, Research Series 11. Morgantown: Office of Research and Development, Appalachian Center, West Virginia University, March 1969.

Scharlach, W. C. and Schuh, G. E. "The Land Market As a Link Between the Rural and Urban Sectors of the Economy," Journal of Farm Economics, Vol. 44, No. 5, Dec. 1962.

Schmid, A. Allan. Converting Land from Rural to Urban Use. Baltimore: The Johns Hopkins Press, 1968.

Schuh, Edward G. and Scharlach, Wesley C. Quantitive Analysis of Some Farm and Non-Farm Determinants of Agricultural Land Values-Impact of Economic Development, Research Bulletin No. 821, Lafayette: Agricultural Experiment Station, Purdue University, 1966.

Scofield, William H. "Prevailing Land Market Forces," Journal of Farm Economics, Vol. 39, No. $5,1957$.

Shafran, Isaac. The Relationship Between the Structure of the Transportation Network and the Economic Development of West Virginia, Research Series 10. Morgantown: Office of Research and Development, Appalachian Center, West Virginia University, March 1969.

Snedecor, George W. and Cochran, William G. Statistical Methods. Ames: The Iowa State University Press, 1971.

Steel, Robert G. and Torrie, James H. Principles and Procedures of Statistics. New York: McGraw-Hill Book Company, Inc. 1960.

Stockwell, Edward G. and Dixon, John P. Social and Economic Change at Interchange Areas of the Connecticut Trunpike, 1958-1964, Research Report 16. Storrs: Storrs Agricultural Experiment Station, The University of Connecticut, Oct. 1966.

Tweeten, Luther G. and Martin, James E. "A Methodology for Predicting U.S. Farm Real Estate Price Variation," Journal of Farm Economics, Vol. 48, No. 2, May 1966.

VanKirk, Fred. Public Facility Location Determinations and Impact of New Highway Investment on Accessibility Changes in a Specific Subregion of West Virginia, Research Series 12. Morgantown: Office of Research and Development, Appalachian Center, West Virginia University, March 1969.

Whetzel Jr., Virgil L. Reservoir Impacts on Economic Activity, Land Use, and Land Values in Appalachia. Morgantown: West Virginia University, Unpublished Master's Thesis, 1969.

Wiecking, E. H. "Farm Real Estate Values," Journal of Farm Economics, Vol. XV, No. 2, April 1933. 
Monongalia County Comprehensive Plan, Phase 1-Basic Research, Surveys, Analysis. Ohio: Carroll V. Hill and Associates, Planning Consultants, Columbus.

Preston County Comprehensive Development Plan, Phase 1-Basic Research, Surveys, and Analysis. Ohio: Candeub, Fleissig, and Associates, Planning and Community Development Consultants, Columbus, 1968.

"Indexes of Farm Real Estate Values Per Acre, 1912-1973," Farm Real Estate Market Developments, Econic Research Service, U. S. Department of Agriculture, Washington, D. C. Supplement No. 2, June 1973. 
Y Price Per Acre, for land and improvements

$\mathrm{X}_{1}$ Average Slope of Land

$\mathrm{X}_{2}$ Average Land Capability Class

$\mathrm{X}_{3}$ Sewage Limitation

$\mathrm{X}_{4}$ Land Cleared

$\mathrm{X}_{5}$ County

$\mathrm{X}_{6}$ Distance to Morgantown (Driving distance)

$\mathrm{X}_{7}$ Distance to Nearest Corridor E Interchange (Direct distance)

$\mathrm{X}_{8}$ Type of Road

X9 Public Water Available

$\mathrm{X}_{10}$ Located in a Subdivision

$\mathrm{X}_{11}$ Number of Parcels in Block Location

$\mathrm{X}_{12}$ Year of Transfer

$\mathrm{X}_{13}$ Acres in Parcel

$\mathrm{X}_{14}$ Grantor Tax Class

$\mathrm{X}_{15}$ Highway Frontage Per Acre

$\mathrm{X}_{16}$ Year By Distance to Interchange $\left(\mathrm{X}_{7} \times \mathrm{X}_{12}\right)$

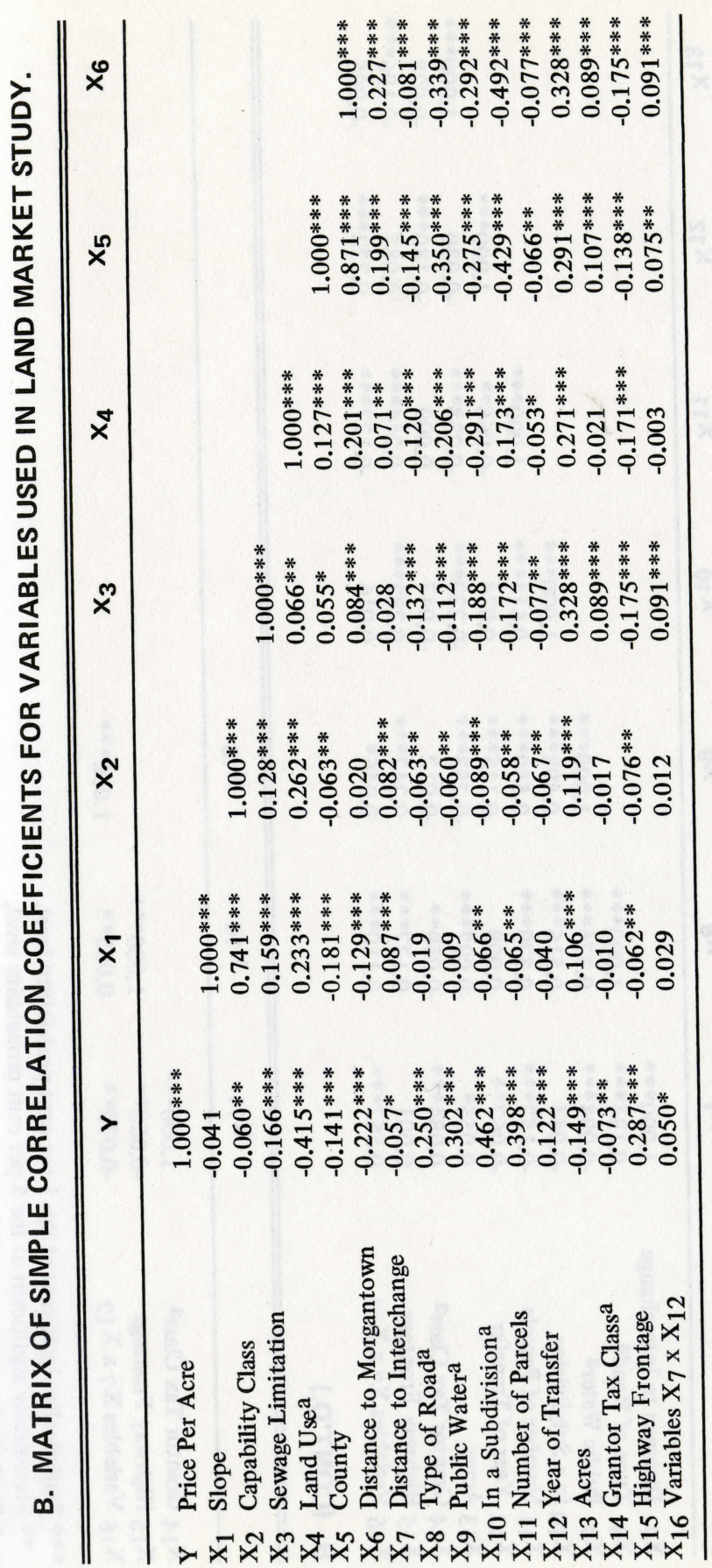




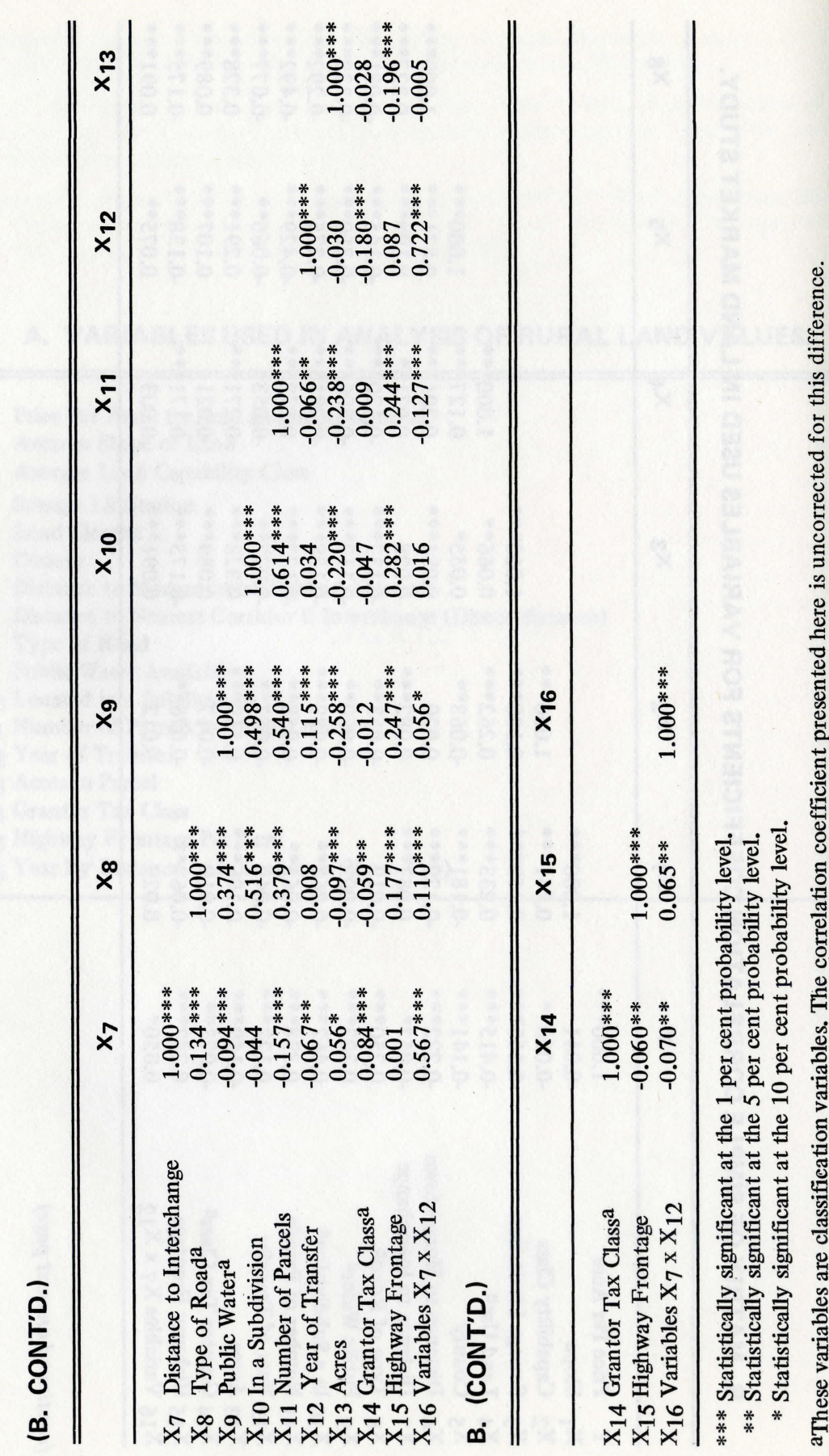

